\title{
Three-dimensional culture of single embryonic stem- derived neural/stem progenitor cells in fibrin hydrogels: neuronal network formation and matrix remodelling
}

\author{
Ana R. Bento',2,3, Pedro Quelhas1,2, Maria J. \\ Oliveira 1,2,4, Ana P. Pêgo 1,2,3,5 and Isabel F. Amaral1,2,3*
}

\author{
${ }_{1}$ INEB - Instituto de Engenharia Biomédica, Universidade do Porto, Portugal \\ ${ }_{2}^{2} 3_{S}$ - Instituto de Investigação e Inovação em Saúde, Universidade do Porto, Portugal \\ 3Faculdade de Engenharia, Universidade do Porto, Portugal \\ 4Departamento de Patologia e Oncologia da Faculdade de Medicina da Universidade do Porto de \\ Medicina da Universidade do Porto, \\ Portugal \\ IInstituto de Ciências Biomédicas Abel Salazar, Universidade do Porto, Portugal \\ *Correspondence to: Isabel F. Amaral, i3S - Instituto de Investigação e Inovação em Saúde, \\ Universidade do Porto, Portugal. E-mail: iamaral@ineb.up.pt
}

Originally published in J Tissue Eng Regen Med. 2017 Dec;11(12):3494-3507. doi: 10.1002/term.2262. Epub 2016 Dec 29.

"This is the peer reviewed version of the following article: Bento, A.R., Quelhas, P., Oliveira, M.J., Pêgo, A.P., Amaral, I.F. "Three-dimensional culture of single embryonic stem-derived neural/stem progenitor cells in fibrin hydrogels: neuronal network formation and matrix remodelling" Journal of Tissue Engineering and Regenerative Medicine 2017, 11(12), 3494-3507, which has been published in final form at https://doi.org/10.1002/adfm.201705920. This article may be used for non-commercial purposes in accordance with Wiley Terms and Conditions for Use of Self-Archived Versions."

\section{ABSTRACT}

In an attempt to improve the efficacy of neural stem/progenitor cell (NSPC) based therapies, fibrin hydrogels are being explored to provide a favourable microenvironment for cell survival and differentiation following transplantation. In the present work, the ability of fibrin to support the survival, proliferation, and neuronal differentiation of NSPCs derived from embryonic stem (ES) cells under monolayer culture was explored. Single mouse ES-NSPCs were cultured within fibrin (fibrinogen concentration: $6 \mathrm{mg} / \mathrm{ml}$ ) under neuronal differentiation conditions up to 14 days. The ESNSPCs retained high cell viability and proliferated within small-sized spheroids. Neuronal differentiation was confirmed by an increase in the levels of $\beta$ III-tubulin and NF20o over time. At day 14 , cell-matrix constructs mainly comprised NSPCs and neurons (46.5\% $\beta$ III-tubulin+ cells). Gamma- 
aminobutyric acid (GABA)ergic and dopaminergic/noradrenergic neurons were also observed, along with a network of synaptic proteins. The ES-NSPCs expressed matriptase and secreted MMP-2/9, with MMP-2 activity increasing along time. Fibronectin, laminin and collagen type IV deposition was also detected. Fibrin gels prepared with higher fibrinogen concentrations $(8 / 10 \mathrm{mg} / \mathrm{ml})$ were less permissive to neurite extension and neuronal differentiation, possibly owing to their smaller pore area and higher rigidity. Overall, it is shown that ES-NSPCs within fibrin are able to establish neuronal networks and to remodel fibrin through MMP secretion and extracellular matrix (ECM) deposition. This three-dimensional (3D) culture system was also shown to support cell viability, neuronal differentiation and ECM deposition of human ES-NSPCs. The settled $3 \mathrm{D}$ platform is expected to constitute a valuable tool to develop fibrin-based hydrogels for ES-NSPC delivery into the injured central nervous system

Keywords: three-dimensional culture; neural stem cells; neuronal maturation; fibrin hydrogel; extracellular matrix; fibronectin; laminin; matrix metalloproteinase activity

\title{
1 INTRODUCTION
}

Nervous system disorders such as spinal cord injury $(\mathrm{SCl})$, stroke, brain trauma and neurodegenerative diseases often result in life-long neurological deficits, with high burden to society and health systems. Regeneration of damaged central nervous system (CNS) tissue remains a challenging issue, as it comprises the regrowth of disrupted axons, the replacement of lost neural cells and the recovery of lost neural functions (Okano, 2010). As in the adult CNS the intrinsic capacity of endogenous neural progenitors to replace lost cells is insufficient, transplantation of exogenous neural stem/progenitor cells (NSPCs) has emerged as a possible therapy to compensate for injuryinduced lost cells. In addition to secreting cytokines with neurotrophic and immunodulatory effect, NSPCs are able to differentiate into neurons and glial cells, potentially contributing to the remyelinization of spared axons and to the establishment of relay neuronal circuitries. In preclinical models of SCl and ischaemic stroke, transplanted NSPCs were shown to be capable of dividing, differentiating and integrating into the injured tissue, partly overcoming functional deficits (Lindvall and Kokaia, 2010; Okano, 2010; Lu et al., 2012). These findings led to the approval of clinical trials to assess the safety and preliminary efficacy of human fetal CNS-derived neural stem cell transplantation (https://clinicaltrials.gov).

Embryonic stem (ES) cells have been explored as an alternative source of NSPCs because of their pluripotency and unlimited capacity for self-renewal (McDonald et al., 2004, Colombo et al., 2006), particularly after the establishment of protocols to efficiently and reproducibly specify ES cells into pure populations of NSPCs (Ying et al., 2003; Incitti et al., 2014). Moreover, ES-derived NSPCs (ESNSPCs) retain a higher proliferative capacity and neuronal differentiation efficiency compared with somatic NSPCs (Colombo et al., 2006), which can be of interest to counteract the high levels of cell death occurring following transplantation. Clinical trials involving ES-NSPC transplantation have also been approved (Geron Corporation, CA 94025, USA; Cell Cure Neurosciences Ltd, Jerusalem, Israel; Ocata Therapeutics Inc., MA 01752, USA; Chabiotech Co Ltd, Seoul, South Korea), as ES-NSPCs were shown to survive, divide, differentiate and promote functional recovery in rodent models of $\mathrm{SCI}$ (McDonald et al., 2004; Erceg et al., 2010).

Despite their functional benefits, NSPCs implanted as suspensions usually show poor cell survival, as well as limited differentiation along the neuronal lineage, as a result of the inhibitory milieu of the injured tissue (McDonald et al., 2004). Attempts are being made to improve NSPC transplantation

\section{西}


efficacy by combining NSPCs with biodegradable hydrogels (Pego et al., 2012). In addition to providing a structural support for axonal extension and allowing a homogenous distribution of transplanted cells, hydrogels contribute to sequester cell-secreted neurite-promoting factors and extracellular matrix $(E C M)$ proteins, while supporting the exchange of nutrients within the surrounding tissue. Hydrogels may therefore contribute to the establishment of a more favourable microenvironment for NSPC survival and differentiation, and for regeneration (Aurand et al., 2012; Pego et al., 2012). Fibrin (Fb) is a Food and Drug Administration (FDA) approved hydrogel with widespread clinical use that emerged as a promising biomatrix for application in the CNS, either as an acellular graft (Petter-Puchner et al., 2007) or as a vehicle for cell and drug delivery (Amaral et al., 2011; Lu et al., 2012). Fibrin is a natural polymer formed during the blood coagulation cascade from its zymogen form, fibrinogen, with a central role in haemostasis. Owing to its mechanical properties, inherent biocompatibility and susceptibility to proteolytic degradation, Fb constitutes a suitable matrix for cells normally residing in soft tissues such as brain or spinal cord (Janmey et al., 2009) and, in this sense, has been successfully explored for the transplantation of NSPCs (Lu et al., 2012).

Commitment of ES cells into the neural fate is usually achieved by inducing embryoid body (EB) formation in suspension culture followed by treatment with retinoic acid (Ying and Smith, 2003). It has been shown that EBs containing neural progenitors proliferate and differentiate following embedment in fibrin hydrogels (Willerth et al., 2006). However, neural induction protocols relying on EB formation typically result in a heterogeneous cell population because of the establishment of concentration gradients of morphogens present from the outer edge of the multicellular aggregates to the core (Dhara and Stice, 2008; Wilson et al., 2014). This issue can be overcome using adherent monoculture systems to generate NSPCs from ES cells, which result in a more homogeneous population ( $>85 \%$ of cells expressing SOX 1 ), because of uniform exposure of cells to soluble factors (Ying and Smith 2003; Dhara and Stice 2008; Chambers et al., 2009).

In this sense, the aim of this work was to establish the conditions for the three-dimensional (3D) culture of NSPCs derived from ES cells under adherent monoculture in fibrin hydrogels, when seeded as single cell suspension. For this purpose, mouse ES-NSPCs were embedded within Fb hydrogels as single cells, and the seeding density leading to the highest cell viability, after 14 days of culture under differentiation conditions, was established. NSPC-Fb constructs were then characterized in terms of cell morphology, proliferation, morphology, phenotype, distribution of cell-secreted ECM proteins, as well as in terms of matrix metalloproteinase (MMP) activity and matriptase expression. Moreover, the effect of fibrinogen concentration on NSPC viability, migration, proliferation, neuronal differentiation and MMP activity was assessed, as the density of bioactive domains and the structural and viscoelastic properties of hydrogels may have an impact on the behaviour of encapsulated cells (Aurand et al., 2012). Finally, to reveal whether or not this 3D culture system could be applied to human ES-derived NSPCs (hES-NSPCs), dissociated hES-NSPCs were cultured within Fb hydrogels for periods up to 21 days and cell viability, neuronal differentiation and ECM remodelling subsequently assessed.

\section{Materials and methods}

\subsection{Generation of NSPCs from mouse ES cells}

The mouse ES cell line (46C) established at the Institute for Stem Cell Research (Edinburgh University, Edinburgh, Scotland, UK) expressing green fluorescent protein (GFP) under the promoter

\section{.}


of the neural-specific Soxi gene, was used (Aubert et al., 2003). The ES 46 cells were grown in KnockOut ${ }^{\mathrm{TM}}$ ESC/iPSC medium (Gibco; Thermo Fisher Scientific, MA 02451, USA) supplemented with $1 \%(v / v)$ penicillin/streptomycin (Pen/Strep), 2 $\mu \mathrm{m}$ GSK-3 inhibitor IX (Calbiochem; Merck, Darmstadt, Germany), and $2 \mathrm{ng} / \mathrm{ml}$ recombinant murine leukaemia inhibitory factor (LIF, produced in bacteria; a gift from Dr Cláudia Lobato, IST, Lisbon, Portugal), in six-well tissue culture-grade plates coated with $0.1 \%(\mathrm{w} / \mathrm{v})$ gelatin (Sigma-Aldrich, MO 63103, USA). Cell culture medium was refreshed every day. To start the monolayer culture protocol, ES cells were cultured at high density $\left(1 \times 10^{5}\right.$ cells $\left./ \mathrm{cm}^{2}\right)$ for $24 \mathrm{~h}$ with LIF (Ying and Smith, 2003). To induce the neural phenotype, ES cells were cultured in monolayer in N2B27 medium, a 1:1 mixture of DMEM/F12 medium supplemented with modified N2 (Ying et al., 2003) with Neurobasal medium supplemented with B27 and Iglutamine (Neurobasal/B27), containing $1 \%$ (v/v) penicillin/streptomycin (all from Gibco). Cell culture medium was refreshed every other day. At day 5 of the monolayer culture differentiation protocol, SOX1-GFP expression was analysed by fluorescence microscopy and flow cytometry, to assess the efficiency of neural conversion (see the Supplementary material online, Figure $\mathrm{S}_{1} \mathrm{~A}, \mathrm{~B}$ ). For the latter, cells were dissociated using StemPro ${ }^{\circledR}$ Accutase ${ }^{\circledR}$ (Gibco), counted, suspended in fluorescenceactivated cell sorting (FACS) buffer [2\% (v/v) fetal bovine serum (FBS) in phosphate-buffered saline (PBS)], and run on a flow cytometer (FACSCalibur TM; BD Biosciences, CA 95131, USA). Live cells were gated based on forward scatter (size) and side scatter (cell complexity) criteria, and fluorescence gates set using undifferentiated $46 \mathrm{C}$ ES cells as a negative control. All analysis was performed using (FlowJo software, LLC; OR 97520, USA). The levels of SOX1-GFP expression of the ES-NSPCs used throughout this study are shown in the Supplementary material online (Figure $\mathrm{S}_{1} \mathrm{~B}$ ), together with a representative fluorescence histogram. The phenotypic characterization of ES-NSPCs at day 5 of monolayer culture neural commitment is provided in the Supplementary material online (Figure $\mathrm{S} 1$ ).

\subsection{Culture of mES-NSPCs within Fb gels}

Fibrinogen solution was prepared dissolving plasminogen-free fibrinogen from pooled human plasma containing factor XIII (Sigma) in ultrapure water, followed by dialysis against Tris-buffered saline (TBS, pH 7.4) for $24 \mathrm{~h}$ (Schense and Hubbell, 1999). The resulting fibrinogen solution was then sterile-filtered and its concentration determined by UV spectroscopy. Fibrinogen solution was then diluted to $12 \mathrm{mg} / \mathrm{ml}$ with sterile TBS. Fibrin gels (total volume $50 \mu \mathrm{l}$ ) were obtained by mixing equal volumes of the fibrinogen solution and a thrombin solution in TBS containing $\mathrm{CaCl}_{2}$ and aprotinin [final concentration of Fb components: $6 \mathrm{mg} / \mathrm{ml}$ fibrinogen; 2 National Institute of Health (NIH) U/ml thrombin from human plasma; $2.5 \mathrm{~mm} \mathrm{CaCl}$ (Merck); $25 \mu \mathrm{g} / \mathrm{ml}$ aprotinin (all Sigma-Aldrich except for $\left(\mathrm{CaCl}_{2}\right)$ ]. The ES-NSPCs were dissociated into single cells and suspended in the fibrinogen solution before transferring the polymerizing solution to the wells of six-well plates. Different cell seeding densities were initially tested $\left(1,2\right.$ and $\left.3 \times 10^{6} \mathrm{NSPCs} / \mathrm{ml}\right)$ in order to optimize the cell seeding density within $\mathrm{Fb}$ gels. Fibrin gels were allowed to polymerize for $30 \mathrm{~min}$ at $37^{\circ} \mathrm{C}$ in a $5 \% \mathrm{CO}_{2}$ humidified incubator before the addition of cell culture media $(3 \mathrm{ml} /$ well). The cell-matrix constructs were cultured for periods up to 14 days in the presence of $5 \mu \mathrm{g} / \mathrm{ml}$ of aprotinin to delay Fb gel degradation, following a protocol for neuronal differentiation (Conti et al., 2005). Cells were initially cultured in $\mathrm{N}_{2} \mathrm{~B}_{27}$ supplemented with $10 \mathrm{ng} / \mathrm{ml}$ basic fibroblast growth factor (bFGF; PeproTech) and, at day 2 of culture, the medium was switched to N2B27-Neurobasal/B27 (1:1) mix without growth factor. At day 8 , half of the medium was replaced by the $\mathrm{N}_{2} \mathrm{~B}_{27-N e u r o b a s a l / B 27}$ (1:3) mix supplemented with $20 \mathrm{ng} / \mathrm{ml}$ brain-derived neurotrophic factor (BDNF) and $50 \mathrm{ng} / \mathrm{ml}$ nerve growth factor (NGF) (both from PeproTech EC Ltd.; London, United Kingdom). Half of the medium was changed every other day. To assess the effect of fibrinogen concentration on ES-NSPC behaviour within Fb, Fb gels with

INSTITUTO DEINVESTİGAÇÃO E INOVAÇÃO EM SAÚDE UNIVERSIDADE DO PORTO

Rua Alfredo Allen, 208 4200-135 Porto Portugal +351220408800 info@i3s.up.pt www.i3s.up.pt 
4, 6, 8 and $10 \mathrm{mg} / \mathrm{ml}$ fibrinogen concentrations were prepared. The ES-NSPCs were embedded within Fb hydrogels and cultured as described above.

\subsection{Culture of human ES-NSPCs within Fb gels}

H9-derived human (h) ES-NSPCs were purchased from Life Technologies and expanded according to the manufacturer's protocol (Gibco; Thermo Fisher Scientific, MA 02451, USA). For cell embedment in Fb, hES-NSPCs were dissociated into single cells using StemPro Accutase and further suspended in Fb gel $\left(1 \times 10^{6} \mathrm{NSPCs} / \mathrm{ml}\right)$ as described for mES-NSPCs. The cell-matrix constructs were cultured for periods up to 21 days in the presence of $5 \mu \mathrm{g} / \mathrm{ml}$ of aprotinin. Human ES-NSPCs were initially cultured in StemPro NSC SFM media (Gibco) containing bFGF and EGF and, at day 2 of culture, the medium was switched to the StemPro NSC SFM media-Neurobasal/B27 (1:1) mix, without growth factors. At day 8, half of the medium was replaced by the StemPro NSC SFM-Neurobasal/B27 (1:3) mix supplemented with $10 \mathrm{ng} / \mathrm{ml}$ of BDNF and $500 \mu \mathrm{m}$ of dibutyryl cAMP (Sigma). Half of the medium was changed every other day.

\subsection{Size of cellular spheroids formed within Fb gels}

The size of the cellular spheroids present within $\mathrm{Fb}$ was assessed at day 14 of culture. Phase contrast images of the cell-Fb constructs were acquired (Axiovert 200; Carl Zeiss), and the diameter size of each spheroid measured using AxioVision software (Carl Zeiss; Oberkochen, Germany). Spheroids smaller than $25 \mu \mathrm{m}$ diameter were not considered, as these mainly corresponded to single or paired cells (Mori et al., 2006).

\subsection{Immunocytometry}

Immunocytometric analysis was performed in six-pooled Fb drops, after cell isolation from the cell$\mathrm{Fb}$ constructs. In brief, the constructs were washed twice with PBS and sequentially incubated with $1.25 \mathrm{mg} / \mathrm{ml}$ of collagenase type II (Gibco; $1 \mathrm{~h}$ at $37^{\circ} \mathrm{C}$ ) and $1 \times$ trypsin-EDTA (Gibco; $30 \mathrm{~min}$ at $37^{\circ} \mathrm{C}$ ) under stirring (70 rpm). After trypsin inactivation with serum-containing media cells were gently dissociated, centrifuged and suspended in cell culture medium. For staining of intracellular markers, cells were fixed with $1 \%(\mathrm{w} / \mathrm{v})$ paraformaldehyde (PFA; 20 min at $\left.4^{\circ} \mathrm{C}\right)$, and permeabilized with $0.2 \%$ $(\mathrm{v} / \mathrm{v})$ Triton $\mathrm{X}-100\left(10 \mathrm{~min}\right.$ at $4^{\circ} \mathrm{C}$ ). Cells were then incubated in blocking buffer for $20 \mathrm{~min}$ and incubated for 30 min with primary antibodies diluted in PBS containing $1 \%(\mathrm{v} / \mathrm{v})$ normal goat serum (NGS; Biosource International Inc., CA 93012, USA) and 0.1\% (w/v) saponin. Primary antibodies were detected by applying isotype-specific or species-specific secondary antibodies for $30 \mathrm{~min}$. For immunolabelling of cell surface markers, the fixation and permeabilization steps were omitted, and the blocking/primary antibody solutions prepared without saponin. Cells were finally washed three times and suspended in FACS buffer containing sodium azide, for flow cytometry analysis (BD FACSCalibur). Primary and secondary antibodies are listed in the Supplementary material online, Table S1. Unlabelled cells were used to set fluorescence gates. Cells stained with secondary antibody only or with the correspondent isotype control were used to assess the background fluorescence associated with non-specific binding of the secondary antibody. Representative fluorescence histograms are shown in the Supplementary material online, Figure $\mathrm{S}_{3} \mathrm{~B}$.

\subsection{Immunocytochemistry}


Immunocytochemistry was performed in cell-Fb constructs previously fixed in cell culture media containing $2 \%(\mathrm{v} / \mathrm{v})$ PFA ( $30 \mathrm{~min}$ at $37^{\circ} \mathrm{C}$ ). All subsequent steps were performed under stirring (50 r.p.m.). When staining for intracellular markers cell-Fb constructs were permeabilized for $45 \mathrm{~min}$ with $0.2 \%(\mathrm{v} / \mathrm{v})$ Triton X-100. Cell-Fb constructs were blocked for $1 \mathrm{~h}$, incubated (overnight at $4^{\circ} \mathrm{C}$ ) with the appropriate primary antibody, rinsed three times with PBS, and incubated for $1 \mathrm{~h}$ with the appropriate secondary antibody. When necessary, nuclei were counterstained with 4, 6-diamidino2-phenylindole (DAPI, $0.1 \mu \mathrm{g} / \mathrm{ml}$; Gibco;). Samples were finally mounted in Fluoromount mounting media (Sigma-Aldrich) and observed under confocal laser scanning microscopy (CLSM) (TCS SP5 II; Leica Microsystems, Germany). Primary and secondary antibodies are listed in the Supplementary material online, Table S2.

\subsection{Cell outward migration analysis}

Neurite extension/cell outward migration from cellular spheroids was assessed at day 4 of ES-NSPC culture within $\mathrm{Fb}$. Cell-Fb constructs were fixed and permeabilized as described for immunocytochemistry studies, incubated with PBS containing $1 \%(w / v)$ BSA for 1 h under stirring, and then for $1 \mathrm{~h}$ under stirring with Alexa Fluor 594-conjugated phalloidin (1:40; Invitrogen; Thermo Fisher Scientific, MA 02451, USA), for visualization of filamentous actin (F-actin). After rinsing with PBS, nuclei were counterstained with DAPI and samples mounted in Fluoromount. Fluorescence images were collected under CLSM. Spheroid and F-actin positive regions were obtained using automatic segmentation of the two-dimensional (2D) maximum intensity projections of DNA and Factin CLSM image stacks, respectively. Given the segmented regions, the number of cell extensions protruding from the edge of each spheroid (sprouts), as well as the length of the longest sprout (maximal outgrowth), were analysed (Bessa et al., 2013). For each condition, 10 randomly selected spheroids from 2 different Fb gels were examined.

\subsection{Microstructure analysis of Fb gels}

Fibrin gels microstructure was characterized using fluorescently-labelled fibrinogen. Fluorescent $\mathrm{Fb}$ gels were prepared as described above, using a 1:100 ratio of Alexa Fluor 488 human fibrinogen conjugate (Molecular Probes; Thermo Fisher Scientific, MA 02451, USA) to unlabelled fibrinogen. Acellular $\mathrm{Fb}$ gels were allowed to polymerize ( $30 \mathrm{~min}$ at $37^{\circ} \mathrm{C}$ ), and immediately observed under CLSM, using a Plan-Apochromat $\times 63 / 1.4$ NA Oil objective. CLSM stacks of 10 optical sections covering a depth of $10 \mu \mathrm{m}$ were acquired, and 2D projected. Pores were automatically segmented and their areas computed using (MATLAB software MathWorks ${ }^{\circledR}$; MA 01760-2098, USA). Finally, the average pore area was determined. For each condition, four images from two different $\mathrm{Fb}$ gels were analysed.

\subsection{Rheological analysis of Fb gels}

A Kinexus Pro Rheometer (Malvern Instruments Ltd, Malvern, United Kingdom) was used to examine the viscoelastic properties of acellular $\mathrm{Fb}$ drops. Fibrin polymerizing solution $(50 \mu \mathrm{l})$ was pipetted into a plate-plate geometry ( $4 \mathrm{~mm}$ in diameter with sandblasted surfaces) previously set at $37^{\circ} \mathrm{C}$, and allowed to polymerize in situ for $1 \mathrm{~h}$ under a humidified atmosphere. A $10 \%$ compression was then applied to the gel to avoid slippage. For each condition, the linear viscoelastic region (LVR) was first determined performing stress sweeps (frequency $0.1 \mathrm{~Hz}$, strain 1-100\%). Frequency sweeps (frequency $0.01-10 \mathrm{~Hz}$, strain $5 \%$ ) were then performed within the LVR. The storage modulus (G'), a measure of the elastic energy stored during the deformation imposed by one oscillation of the 
rheometer, was determined and used as a measure of Fb drop stiffness. The loss modulus (G"), which reflects the energy dissipated by $\mathrm{Fb}$ drops during deformation was also recorded. Six Fb gels were analysed per condition.

\subsection{Data analysis and statistics}

Each independent experiment was established from mES-NSPCs obtained from different neural commitments. In each flow cytometry analysis, 10000 events were captured inside the gate. Sample distribution was tested for normality using the Kolmogorov-Smirnov test, and data subsequently analysed using the unpaired $t$-test. Unless mentioned otherwise, all data are presented as mean \pm standard deviation (SD). The statistical significance level was set for $p$-values $<0.05$.

A detailed description of the methods used to culture mES-NSPCs on 2D substrates, as well as to assess cell viability, total cell number, proliferation, and the levels of MMP activity, matriptase, $\beta I I I-$ tubulin and NF200 is provided in the Supplementary material online (Methods S1).

\section{Results}

\subsection{Optimization of $\mathrm{mES}$-NSPC cell seeding density within Fb}

To assess the optimal conditions to culture mES-NSPCs within $\mathrm{Fb}$, different cell seeding densities were initially explored $\left(1,2\right.$ and $3 \times 10^{6}$ cells $\left./ \mathrm{ml}\right)$. Following entrapment within $\mathrm{Fb}$, single ES-NSPCs were found well dispersed within the $\mathrm{Fb}$ gel, as shown by incubation of samples with calcein $\mathrm{AM}$ and Hoechst (see the Supplementary material online, Figure $\left.S_{2} A\right)$. The lowest cell seeding density ( $1 \times$ $10^{6} \mathrm{cell} / \mathrm{ml}$ ) resulted in a lower number of dead cells and smaller-sized cellular spheroids after 14 days of culture, as shown by CLSM analysis of cell/Fb constructs previously incubated with calcein AM/propidium iodide (PI) (see the Supplementary material online, Figure S2B). These qualitative results were further supported by flow cytometry analysis of cell viability, which showed, for the lowest cell seeding density, the lowest percentage of PI-labelled cells (see the Supplementary material online, Figure $\mathrm{S}_{2} \mathrm{C}$ ). As a result, this cell seeding density was selected for use in subsequent studies. The cell culture medium was supplemented with aprotinin, a cell protease inhibitor, as the mere addition of aprotinin to the Fb polymerizing solution was not sufficient to preserve cell-Fb construct integrity during the 14 days of culture (see the Supplementary material online, Figure S2D). The addition of $5 \mu \mathrm{g} / \mathrm{ml}$ of aprotinin to the medium was effective in preventing the overall $\mathrm{Fb}$ gel degradation, independently of the cell seeding density tested, while being permissive to $\mathrm{Fb}$ degradation by migrating cells (data not shown).

\subsection{Cell viability and proliferation of mES-NSPCs within Fb gels}

The distribution of live/dead cells within Fb gels was assessed after 7 days and 14 days of culture. Confocal analysis of cell-Fb constructs, previously incubated with calcein AM/PI, showed for both time-points the presence of live cells widely distributed throughout the Fb gel, often growing as cellular spheroids. Formation of cellular spheroids was associated with proliferative capacities and not with aggregation at the initial cell embedment, as only single cells were detected within Fb gels immediately after cell embedment (see the Supplementary material online, Figure S2A). Neurite-like extensions were observed at day 7 , and at day 14 of culture; these formed a dense network of cellular processes (Figure 1 a). Uptake of PI by cells was also observed at both time-points analysed. The

\section{.}


quantitative analysis of live/dead cells within $\mathrm{Fb}$ was assessed by flow cytometry, upon cell isolation from the Fb gels. Cell viability within Fb gels was found to be similar at both time-points and at levels greater than $85 \%$, on average, as demonstrated by the percentage of cells excluding PI (Figure $\underline{1}$ b). The percentage of cells remaining alive was found to be high for both time-points considered, as shown by the percentage of cells retaining ability to hydrolyse calcein AM (99.9\% for day 7 and $94.3 \%$ for day $1_{4 ;}$ see the Supplementary material online, Figure S3A). The ES-NSPCs within Fb gels were able to proliferate, as demonstrated by the fivefold and twofold increase in cell number found over the first and second weeks of culture, respectively (Figure $1 \mathrm{c}$ ). At day 14 of culture, the presence of small-sized cellular spheroids inside cell-Fb constructs, mostly frequently with diameters in the range of $50-75 \mu \mathrm{m}$ (Figure $1 \mathrm{~d}$ ), also suggests cell proliferation of ES-NSPCs within Fb.

\subsection{Phenotypic analysis of mES-NSPCs cultured within Fb gels}

Differentiation into the neuronal lineage over the cell culture period was initially followed by western blot of $\beta$ III-tubulin (developing and mature neurons) and NF200 (mature neurons). As expected, expression of $\beta I I I$-tubulin and NF200 was not detected before ES-NSPC embedment in Fb (data not shown). Throughout the culture period, the expression of these neuronal markers increased, attaining significantly higher levels at day 14 when compared with day 4 for both markers (Figure $2 \mathrm{a}, \mathrm{b}$ ). For this reason, a more detailed phenotypic analysis was performed at day 14 of cell culture by flow cytometry and immunocytochemistry (Figure $\underline{2} \mathrm{c}$ ). At this time-point, a significant percentage of cells still expressed the NSPC marker nestin $(53.1 \pm 6.3 \%)$ and the neural stem cell (NSC) marker Sox1-GFP ( $37.7 \pm 5.6 \%)$. The percentages found were always to be inferior to those of ES-NSPCs before embedment within $\mathrm{Fb}\left(87.7 \pm 5.8 \%\right.$ SOX $1-G F P+^{+}$cells and $86.5 \pm 7.2$ nestin $^{+}$cells; see the Supplementary material online, Figure $\mathrm{S}_{1} \mathrm{C}$ ). Under these conditions, ES-NSPCs differentiated mainly into $\beta$ III-tubulin immunoreactive neurons, as shown by the higher percentage of $\beta I I I-t u b u l i{ }^{+}$ cells found $(46.5 \pm 12.5 \%)$ compared with those of cells staining positive for glial fibrillary acidic protein (GFAP) or $\mathrm{O}_{4}$, astrocytic and oligodendrocytic markers, respectively. After 14 days of culture, the percentage of cells expressing stage-specific embryonic antigen 1 (SSEA-1), a marker for undifferentiated mouse ES cells, dropped from $57.3 \pm 17.6 \%$ (see the Supplementary material online, Figure $\mathrm{S}_{1} \mathrm{C}$ ) to $20.6 \pm 4.7 \%$. CLSM analysis of samples processed for immunofluorescence at this same time-point (day 14) supported the previous results. Images depict cell-matrix constructs composed of a heterogeneous cell population encompassing NSPCs (nestin ${ }^{+}$cells; Figure 2 e) and developing and mature neurons ( $\beta$ III-tubulin ${ }^{+}$and $\mathrm{NF}_{200^{+}}$cells; Figure $\underline{2} h, i$ ). Neurites staining for $\beta$ III-tubulin were found mainly radially extending from cellular spheroids, forming a dense neuronal network throughout the whole Fb gel (Figure $\underline{2} h$ ). Astrocytes and oligodendrocytes were also detected but in lower amounts, and mostly located near the spheroids (Figure $\underline{2} f, g$ ). A reminiscent population marking for SSEA-1 could be also observed at this time (Figure $\underline{2} \mathrm{~d}$ ). The presence of synaptic vesicles was assessed through synapsin immunodetection. Cell-Fb constructs revealed an extensive network of synapsin (Figure 2j]), and the presence of dendritic spines along the axonal processes (arrowheads in Figure 2j). Neuronal phenotype was further investigated. A ubiquitous expression of GAD67, a GABAergic phenotype marker, was observed throughout the cell-Fb constructs (Figure $\underline{2} k$ ). Furthermore, immunodetection of tyrosine hydroxylase $(\mathrm{TH})$ revealed the presence of mature dopaminergic and/or noradrenergic neurons (Figure $\underline{2}$ l); The TH-labelled neurons with long extensions are indicated by arrowheads.

\subsection{Distribution of cell-secreted ECM proteins, MMP activity and matriptase expression in 3D cultures of mES-NSPCs within Fb gels}

(1) 
The distribution of cell-secreted ECM proteins was observed after 14 days of culture through immunodetection of fibronectin, laminin and collagen IV. As fibronectin is a common contaminant in commercially available fibrinogen, acellular $\mathrm{Fb}$ gels were also assessed for the presence of fibronectin, but no positive staining was detected in Fb gels (data not shown). Cell-Fb constructs revealed the presence of cell-secreted fibronectin fibrils following a similar deposition pattern to that described for neurites, and often forming bundles near the cellular spheroids (Figure za). This deposition pattern is in accord with the role of fibronectin as a mediator of neuronal migration and outgrowth during development (Sheppard et al., 1991). A network of laminin was also observed, mainly inside and near cellular aggregates (Figure 3 b). Collagen type IV was also detected at this time-point, whether in the form of a tight network inside cell spheroids or as fibrils deposited within the Fb gel, as depicted by arrowheads in Figure $3 \mathrm{c}$ ). In 2D cultures of ES-NSPCs on poly-dlysine/laminin-coated glass coverslips carried out in parallel, the deposition of these three ECM proteins was also observed (Figure $3 \mathrm{~d}-\mathrm{f}$ ). The activity of MMPs was studied by performing gelatin zymography in conditioned media of ES-NSPC cultures within Fb gel and by loading $20 \mu \mathrm{g}$ of total protein from conditioned media. No MMP activity was detected in Fb gels cultured without cells (data not shown). Zymograms showed that MMP-2 and MMP- 9 were secreted by ES-NSPCs within Fb, the latter being detected at a later period of culture (Figure $3 \mathrm{~g}$ ). The MMP-2 activity levels increased along the culture period, attaining levels significantly higher than those of day 4 of culture at day 14 (Figure 3g). The MMP-9 activity was only detected from day 8 of culture onwards, and no significant differences were found among the different time-points analysed (Figure $3 \mathrm{f}$ ). Matriptase expression of ES-NSPCs cultured within Fb was subsequently investigated, as ES-46C cells were reported to express this protease when cultured on a collagen-coated surface under neuronal differentiation conditions (Fang et al., 2011). Western blot was performed for three independent experiments and matriptase levels normalized to GAPDH expression. As expected, matriptase expression was detected in ES-NSPCs before embedment in Fb (matriptase levels 1.32, data not shown). Significant differences in matriptase expression were only found at day 14 of cell culture, for which 1.3-fold higher levels were found compared with day 8 (Figure 3 h).

\subsection{Effect of fibrinogen concentration on mES-NSPC behaviour within Fb gels}

To assess the effect of fibrinogen concentration on NSPC behaviour within $\mathrm{Fb}$, Fb gels were prepared with $4,6,8$ or $10 \mathrm{mg} / \mathrm{ml}$ of fibrinogen and their structural and viscoelastic properties characterized. Fibrin gels prepared with $4 \mathrm{mg} / \mathrm{ml}$ or $6 \mathrm{mg} / \mathrm{ml}$ of fibrinogen revealed a similar microstructure, while those prepared with higher concentrations of fibrinogen $(8 \mathrm{mg} / \mathrm{ml}$ and $10 \mathrm{mg} / \mathrm{ml})$ showed a denser network of Fb fibre bundles and smaller pore size (Figure $4 \mathrm{a}$ ). Image analysis of 2D projected CLSM stack images further confirmed the qualitative results obtained, revealing a decrease in the average pore area with increasing fibrinogen concentration $(0.71 \pm 0.02,0.65 \pm 0.05,0.53 \pm 0.01$ and $0.49 \pm$ $0.02 \mu \mathrm{m}^{2}$ for fibrinogen concentrations of $4,6,8$ and $10 \mathrm{mg} / \mathrm{ml}$, respectively), which was statistically significant when comparing $\mathrm{Fb}$ gels prepared with $8 \mathrm{mg} / \mathrm{ml}$ or $10 \mathrm{mg} / \mathrm{ml}$ of fibrinogen with those prepared with $4 \mathrm{mg} / \mathrm{ml}$ or $6 \mathrm{mg} / \mathrm{ml}$ of fibrinogen (Figure $4 \mathrm{~b}$ ). Rheological analysis of Fb gels consistently showed a significant increase of the storage ( $\left.G^{\prime}\right)$ and loss modulus ( $\left.G^{\prime \prime}\right)$ with increasing fibrinogen concentrations, with G' always exceeding G" (Figure $4 \mathrm{c}$ ).

The ES-NSPCs were then embedded within Fb gels and cultured for periods up 14 days. The impact of fibrinogen concentration on neurite extension/cell outward migration was assessed at day 4 of culture. Fibrin gels prepared with $8 \mathrm{mg} / \mathrm{ml}$ or $10 \mathrm{mg} / \mathrm{ml}$ of fibrinogen were found to be less permissive 
to neurite extension/cell outward migration compared with gels prepared with $4 \mathrm{mg} / \mathrm{ml}$ and $6 \mathrm{mg} / \mathrm{ml}$ of fibrinogen, as shown by the significant decrease in the number of protruding cellular processes (sprouts) as well as in the maximal outgrowth from cellular spheroids found after image analysis (Figure 5 a). The effect of fibrinogen concentration on neuronal differentiation was investigated at day 14 of culture. Compared with Fb gels with $4 \mathrm{mg} / \mathrm{ml}$ or $6 \mathrm{mg} / \mathrm{ml}$ of fibrinogen, Fb gels prepared with $8 \mathrm{mg} / \mathrm{ml}$ or $10 \mathrm{mg} / \mathrm{ml}$ showed a less dense network of cellular processes labelled for Blll-tubulin (as shown by CLSM; Figure 5 b). After cell isolation from the constructs, flow cytometry analysis also revealed a lower percentage of $\beta$ III-tubulin immunoreactive cells within Fb gels prepared with 10 $\mathrm{mg} / \mathrm{ml}$ of fibrinogen, comparing to those found in $\mathrm{Fb}$ gels prepared with 4 or $6 \mathrm{mg} / \mathrm{ml}$ of fibrinogen. (Figure $5 \mathrm{c}$ ). The analysis of the mean fluorescence intensity ratio of the histograms (mean fluorescence intensity of cells stained for $\beta$ III-tubulin normalized to that of cells incubated only with secondary antibody), also suggests lower expression of $\beta$ III-tubulin at the single level in Fb gels prepared with $8 \mathrm{mg} / \mathrm{ml}$ and $10 \mathrm{mg} / \mathrm{ml}$ of fibrinogen (Figure $5 \mathrm{~d}$ ), further supporting immunocytochemistry data. Despite hampering neuronal differentiation of ES-NSPCs within Fb, fibrinogen concentration did not affect cell viability, regardless of the fibrinogen concentration considered, as shown by a Trypan Blue dye exclusion assay, performed at day 14 of culture (Figure $5 \mathrm{e}$ ). When analysing the size of cellular spheroids present in cell-Fb constructs at this same time-point, large-diameter spheroids (diameter $\geq 125 \mu \mathrm{m}$ ) were found within Fb gels prepared with 8 $\mathrm{mg} / \mathrm{ml}$ or $10 \mathrm{mg} / \mathrm{ml}$ of fibrinogen (see the Supplementary material online, Figure $\mathrm{S}_{4} \mathrm{~A}$ ). These findings suggest that Fb gels with fibrinogen concentrations $\geq 8 \mathrm{mg} / \mathrm{ml}$ possibly constitute less permissive microenvironments for neurite extension and cell migration, which is in line with the inhibitory effect on cell outward migration observed for fibrinogen concentrations of $8 \mathrm{mg} / \mathrm{ml}$ and $10 \mathrm{mg} / \mathrm{ml}$, at day 4 of culture (Figure 5a). To assess the effect of fibrinogen concentration on cell proliferation, total cell number and the percentage of proliferative cells were determined at day 14 of culture, counting the average number of viable cells per Fb drop and determining the fraction of cells incorporating BrdU (5-bromo-2'-deoxyuridine), respectively. Results obtained showed no significant effect on either the total cell number or the percentage of proliferative cells at this time-point, when varying the fibrinogen concentration (see the Supplementary material online, Figure $\mathrm{S}_{4} \mathrm{~B}, \mathrm{C}$ ). Finally, the effect of fibrinogen concentration on MMP activity present in conditioned media of ES-NSPCs cultured for 14 days within $\mathrm{Fb}$ was also investigated. Except for an increase in MMP-2 activity levels found when increasing the fibrinogen concentration from $8 \mathrm{mg} / \mathrm{ml}$ to $10 \mathrm{mg} / \mathrm{ml}$, no significant differences were found among MMP-9 activity levels when varying the fibrinogen concentration (see the Supplementary material online, Figure S4D).

\subsection{Culture of hES-NSPCs within Fb gels}

It was then investigated whether this $3 \mathrm{D}$ culture model could support the neuronal differentiation of single hES-NSPCs. Confocal analysis of cell-matrix constructs incubated with calcein AM/PI after 14 days of cell culture, showed the presence of live cells widely distributed throughout the $\mathrm{Fb}$ gel growing as cellular spheroids, similarly to mES-NSPCs in Fb (Figure $\underline{6} a$ ). At the same time, the quantitative analysis of live/dead cells isolated from $\mathrm{Fb}$ gels revealed a high percentage of viable cells (98.4\%) and an average of $6.7 \% \mathrm{Pl}^{+}$cells (dead cells; Figure $\underline{6}$ b). Immunocytochemistry analysis showed the presence of nestin+ cells (Figure $\underline{6} c$ ), as well as a population of neurons expressing $\beta$ IIItubulin with neurites radially extending from cellular spheroids (Figure $\underline{6} d$ ). Synaptic proteins (synapsin) with a distribution pattern resembling that of neurites were also observed (Figure $\underline{6} e$ ). Similarly to mES-NSPCs, hES-NSPCs were found to deposit laminin and fibronectin (Figure $\underline{6}, \mathrm{~g}$ ).

INSTITUTO DE INVESTİGAÇÃO E INOVAÇÃO EM SAÚDE UNIVERSIDADE DO PORTO

Rua Alfredo Allen, 208 4200-135 Porto Portugal +351220408800 
Fibronectin deposition was found to be closely associated with neurites expressing BIII-tubulin, as shown by double immunocytochemistry performed at day 21 (Figure $\underline{6} h$ ).

\title{
4 Discussion
}

The present study established the $3 \mathrm{D}$ culture of NSPCs derived from mouse ES cells under adherent monoculture, in fibrin hydrogels. The ES-NSPCs were seeded within Fb in the form of single cells and cultured under neuronal differentiation conditions. Cell viability, morphology, proliferation, phenotype, distribution of cell-secreted ECM proteins, and proteolytic activity were subsequently characterized. Furthermore, the behaviour of ES-NSPCs within $\mathrm{Fb}$ in response to fibrinogen concentration was investigated.

The cell seeding density leading to the highest retention of cell viability in an Fb gel with fixed composition (fibrinogen concentration in the polymerizing gel: $6 \mathrm{mg} / \mathrm{ml}$ ) was initially established. When seeded at $1 \times 10^{6}$ cells $/ \mathrm{ml}$, ES-NSPCs were able to retain in average more than $85 \%$ of cell viability throughout the culture period and to proliferate, as shown by the nine-fold increase in total cell number observed at day 14 of culture (Figure $\underline{1} a-c)$. The high levels of cell viability observed may be associated with the presence of bFGF during the first 2 days of culture, owing to its mitogenic effect on SOX $1^{+}$cells (Ying et al., 2003), as well as to the presence of BDNF and NGF during the last period of culture. These two neurotrophins are important for neuronal survival (Levi-Montalcini and Angeletti, 1963; Shetty and Turner, 1998) which, apart from being constitutively-secreted by NSPCs (Lu et al., 2003), were added to the media. Moreover, the ability of Fb to sequester bFGF and BDNF through its heparin-binding domain (Martino et al., 2013) possibly contributed to their retention within fibrin and to prolong their bioavailability to cells. The addition of aprotinin to cell culture media, a serine protease inhibitor herein used to delay fibrin degradation, may have also contributed to cell viability, as aprotinin was shown to exert neuroprotective effects in vitro (Davis et al., 1975) and to increase cell viability of dissociated embryoid bodies (EBs)-containing neural progenitors in $\mathrm{Fb}$ (Willerth et al., 2006). ES-NSPCs entrapped within Fb as single cells rapidly divided forming sphericalshaped clone-like multicellular clusters. The formation of large-sized cellular spheroids (diameter greater than $300 \mu \mathrm{m}$ ) is often a concern, as this can compromise the delivery of oxygen/nutrients/growth factors to the inner part of the spheroids, and ultimately lead to the formation of necrotic cores (Sen et al., 2001). However, ES-NSPCs seeded at $1 \times 10^{6} \mathrm{cells} / \mathrm{ml}$ resulted in the formation of small-sized spheroids with diameters below values that could compromise cell viability in the core of the spheroids (Figure $\underline{1} \mathrm{~d}$ ). Fibrin was able to sustain a pool of NSPCs, as shown by the high percentage of total cell population expressing the NSC marker SOX1-GFP and the NSPC marker nestin at the end of culture, regardless of bFGF withdrawal from the cell culture medium at day 2 of culture (Figure $\underline{2} c, e$ ). This is an important feature, as hydrogels for delivery of ES-NSPCs should provide an adequate microenvironment for the maintenance of a pool of NSPCs following transplantation, not only because of their potential to differentiate into mature neural cells but also because functional recovery is thought to be mainly mediated by neurotrophic factors secreted by NSPCs (Lu et al., 2003; Ying et al., 2003). Single ES-NSPCs seeded within Fb gels efficiently generated neurons, giving rise to a dense neuronal network ( $46 \%$ of $\beta$ III-tubulin ${ }^{+}$cells; Figure $\underline{2}$ ) and, to a lesser extent, to astrocytes and oligodendrocytes. The capacity of maturation of these neuronal cells was shown by the increase in NF200 expression (Figure $\underline{2}$ b), and detection of GABAergic (GAD67 $7^{+}$cells) and dopaminergic/noradrenergic neurons ( $\mathrm{TH}^{+}$cells), as well as by the presence of a network of synaptic vesicles and dendritic spines (Figure $2 \mathrm{j}-\mathrm{l}$ ). The ability of $\mathrm{Fb}$ to support ES-NSPC differentiation into such neuronal populations (namely, into GABAergic neurons) is valuable, as

\author{
s
}


several therapeutic strategies could profit in the transplantation of cells allowing a long-term supply of GABA (Kim et al., 2010). When differentiated on gelatin-coated surfaces, ES-NSPCs were found to express markers for glutamatergic, serotonergic and motor neuronal subtypes, in addition to GABAergic and dopaminergic markers (Incitti et al., 2014). Still, the ability of Fb to sustain ES-NSPC differentiation into glutamatergic, serotonergic and motor neurons remains an issue to be addressed.

As $\mathrm{Fb}$ acts as a provisional ECM that can be remodelled by invasive cells through cell-secreted proteases and cell-secreted ECM proteins, the ECM proteins distribution and the proteolytic activity in cell/Fb constructs were further analysed. Laminin and fibronectin expression by NSPCs was initially detected in floating aggregates of NSPCs (neurospheres) (Campos 2004), and, more recently, collagen IV and vitronectin were also shown to be present in EB-containing neural progenitors (Sart et al., 2014). It was found that, when cultured within Fb, ES-NSPCs secrete endogenous ECM proteins, namely laminin, fibronectin and collagen type IV, contributing to Fb remodelling (Figure zac). In comparison with laminin or collagen IV, fibronectin showed a wider distribution inside cell-Fb constructs, which can be related to the ability of $\mathrm{Fb}$ to sequester fibronectin through its fibronectin high-affinity binding domains (Brown and Barker, 2014). MMPs are key players in ECM remodelling because of their ability to cleave ECM components such as collagen, laminin and fibronectin (Tonti et al., 2009), as well as to proteolytically degrade fibrinogen and fibrin (Ahmed et al., 2007). Increasing evidence is supporting MMP involvement in neurogenesis, neurite elongation and axonal growth, as well as in synaptogenesis along homeostasis and pathologic events (Tonti et al., 2009; Fujioka et al., 2012). Interestingly, it was observed that ES-NSPCs within Fb secrete MMPs (Figure 3g) which, by locally contributing to ECM and Fb degradation, possibly facilitated neurite extension and cell migration, leading to $\mathrm{Fb}$ remodelling and to the formation of a more mature engineered tissue. In line with this hypothesis, Man et al. (2011) showed that neurite extension from dorsal root ganglia (DRG) explants entrapped in $\mathrm{Fb}$ is dependent on fibrinolysis and on MMPs and serine protease secretion. Interestingly, an increase of MMP-2 activity was found throughout the culture period, suggesting that this protease may play an important role in mediating ES-NSPC neurite extension and cell infiltration within Fb. MMP-9 activity was detected at a later stage of ES-NSPC culture within Fb, in accordance with the progress of neuronal differentiation and maturation observed (Barkho et al., 2008). The expression of matriptase, a type II transmembrane serine protease that acts upstream of MMP-2, promoting ES-NSPC migration and neuronal differentiation (Fang et al., 2011), was also assessed. ES-NSPCs within $\mathrm{Fb}$ retained the ability to express matriptase, showing an increase in matriptase expression during the second week of cell culture (Figure $\underline{2}$ h), in accordance to its role in neuronal differentiation. The present study did not assess the expression of plasmin - one of the major fibrinolytic serine proteases - because ES-NSPCs were cultured within Fb in the presence of aprotinin.

As the structural and viscoelastic properties of hydrogels affect stem cell behaviour and fate (Banerjee et al., 2009; Man et al., 2011), the effect of fibrinogen concentration on NSPC behaviour was assessed. In accord with the literature, changes in fibrinogen concentration are expected to affect $\mathrm{Fb}$ structural and viscoelastic properties to a greater degree when compared to other $\mathrm{Fb}$ components, such as thrombin and calcium (Brown and Barker, 2014). Increasing the fibrinogen concentration resulted in increased $\mathrm{Fb}$ stiffness and in a denser $\mathrm{Fb}$ network with the presence of smaller pores (Figure 4), in agreement with the literature (Brown and Barker, 2014). Still, significantly changes in average pore diameter were only observed when increasing fibrinogen concentration to $8 \mathrm{mg} / \mathrm{ml}$ or $10 \mathrm{mg} / \mathrm{ml}$. In the present study, ES-NSPCS within Fb were found to sense the changes in $\mathrm{Fb}$ viscoelastic and structural properties, as shown by the decrease in both neurite extension/cell 
outgrowth migration and neuronal differentiation in $\mathrm{Fb}$ gels with small-sized pores and stiffer matrices (Figure $5 \mathrm{a}-\mathrm{c}$ ), corresponding to $8 \mathrm{mg} / \mathrm{ml}$ or $10 \mathrm{mg} / \mathrm{ml}$ of fibrinogen. To sustain neuronal differentiation, neurite outgrowth and cell infiltration, Fb gel mechanical properties should ideally match those of native neural tissues while $\mathrm{Fb}$ structural and biological properties should ensure support to cells and provide an adequate density of bioactive domains for integrin/growth factor/ECM binding (Man et al., 2011) The fibrinogen concentrations that induced a better performance of ES-NSPCs within $\mathrm{Fb}$ (in terms of neurite extension, neuronal differentiation, and formation of smaller-size spheroids) were those of $4 \mathrm{mg} / \mathrm{ml}$ and $6 \mathrm{mg} / \mathrm{ml}$, which resulted in Fb gels with a storage modulus comparable to that of neural tissue in the adult brain (400-1000 Pa) (Elkin et al., 2011). The findings are in agreement with previously published studies that reported a decrease in BIII-tubulin expression levels for adult NSCs cultured in alginate gels when increasing the elastic modulus of these gels (Banerjee et al., 2009). In contrast, no decrease in cell proliferation was observed when increasing the elastic modulus of $\mathrm{Fb}$ hydrogels (Figure $\mathrm{S}_{4} \mathrm{C}$ ) in the present study. This result may be related to the lower percentage of BrdU-incorporating cells found at this time-point $(<5 \%)$, which may be too low to allow the detection of significant differences among the fibrinogen concentrations tested. Nevertheless, when considering an in vivo scenario, Fb gels produced with fibrinogen concentrations of $8 \mathrm{mg} / \mathrm{ml}$ and $10 \mathrm{mg} / \mathrm{ml}$ can also be of interest to reduce the polymerization time and the degradation rate (Aurand et al., 2012; Brown and Barker, 2014), as in vitro these $\mathrm{Fb}$ hydrogels also supported neuronal differentiation.

Finally, the present study assessed whether or not this $3 \mathrm{D}$ culture model could support human ESNSPC viability, neuronal differentiation and ECM remodelling. Although the culture of human fetal/adult NSPCs within hydrogels has been extensively explored (either seeded as single cells or as cellular aggregates), only a few studies report the ${ }_{3} \mathrm{D}$ culture of dissociated NSPCs derived from human pluripotent stem cells within hydrogels (Sun et al., 2015; Alessandri et al., 2016). Similar to mES-NSPCs, hES-NSPCs within Fb were found to retain cell viability and sustain a pool of NSPCs, while expressing neuronal and synaptic proteins. These results are in good agreement with the studies of Alessandri et al. (2016), in which NSPCs derived from human induced pluripotent stem cells encapsulated as single cells within Matrigel revealed high retention of cell viability ( $97.8 \%$ of viable cells), with expression of NSPC and neuronal markers. In addition, the present study verifies that hESNSPCs cultured within a $3 \mathrm{D} \mathrm{Fb}$ hydrogel were able to remodel $\mathrm{Fb}$ through cell-secreted fibronectin and laminin - two ECM proteins present in the embryonic neural stem cell niche (Solozobova et al., 2012).

\section{Conclusions}

In the present study, it was shown that mES-NSPCs obtained in adherent monoculture, when seeded within a $\mathrm{Fb}$ hydrogel as dissociated cells remain viable, while retaining the ability to proliferate, differentiate into mature neurons and establish neuronal networks. In this $3 \mathrm{D}$ system, ES-NSPCs were also able to secrete ECM proteins and MMPs, therefore contributing to Fb remodelling and to the formation of a more mature engineered neural tissue. The ES-NSPCs were found to respond to changes in Fb viscoelastic and structural properties, with neurite extension/cell outgrowth migration and neuronal differentiation being hindered in $\mathrm{Fb}$ gels with stiffer matrices and small-sized pores (herein corresponding to gels prepared with $8 \mathrm{mg} / \mathrm{ml}$ or $10 \mathrm{mg} / \mathrm{ml}$ of fibrinogen). This $3^{D}$ culture model was also shown to support cell viability, neuronal differentiation, expression of synaptic proteins and ECM deposition of human ES-NSPCs seeded as single cells within Fb. The settled $3 \mathrm{D}$ platform is expected to constitute a valuable tool for the development of Fb-based hydrogels 
specifically designed for ES-NSPC delivery into the injured CNS. Moreover, it could be of interest for pharmacological screening and to unravel molecular mechanisms implicated in neurogenesis in an in vitro $3 \mathrm{D}$ microenvironment, which better mimics in vivo conditions.

\section{Acknowledgements}

The authors would like to acknowledge Prof. Domingos Henrique (Instituto de Medicina Molecular, Lisbon) for providing the ES $46 \mathrm{C}$ cell line. This work was supported by FEDER funds through the Programa Operacional Factores de Competitividade - COMPETE (FCOMP-01-0124-FEDER-021125) and by National funds FCT - Fundação para a Ciência e a Tecnologia (PTDC/SAU-BMA/118869/2010). A.R.B. and M.J. Oliveira are supported by FCT (SFRH/BD/86200/2012; Investigator FCT).

\section{Conflict of interest}

The authors have declared that there is no conflict of interest.

\section{.}




\section{REFERENCES}

Ahmed TA, Griffith M, Hincke M. 2007; Characterization and inhibition of fibrin hydrogel-degrading enzymes during development of tissue engineering scaffolds. Tissue Eng 13: 1469-1477.

Alessandri K, Feyeux M, Gurchenkov B, et al. 2016; A 3D printed microfluidic device for production of functionalized hydrogel microcapsules for culture and differentiation of human Neuronal Stem Cells (hNSC). Lab Chip 16: 1593-1604.

Amaral IF, Ferreira AR, Veiga D, et al. 2011; Evaluation of a fibrin gel for transplantation of embryonic stem-derived neuroprogenitors into the injured spinal cord. Histol Histopathol Cell Molec Biol 26(Suppl 1): 291-292.

Aubert J, Stavridis MP, Tweedie S, et al. 2003; Screening for mammalian neural genes via fluorescence-activated cell sorter purification of neural precursors from Sox1-gfp knock-in mice. Proc Natl Acad Sci U S A 100: 11836-11841.

Aurand ER, Lampe KJ, Bjugstad KB. 2012; Defining and designing polymers and hydrogels for neural tissue engineering. Neurosci Res 72: 199-213.

Banerjee A, Arha M, Choudhary S, et al. 2009; The influence of hydrogel modulus on the proliferation and differentiation of encapsulated neural stem cells. Biomaterials 30: 4695-4699.

Barkho BZ, Munoz AE, Li XK, et al. 2008; Endogenous matrix metalloproteinase (MMP)-3 and MMP-9 promote the differentiation and migration of adult neural progenitor cells in response to chemokines. Stem Cells 26: 31393149 .

Bessa S, Quelhas P, Amaral I. 2013; Automatic quantification of cell outgrowth from neurospheres. In Pattern Recognition and Image Analysis (J Sanches, L Micó, J Cardoso eds), pp. 141-48. Springer, Berlin Heidelberg.

Brown AC, Barker TH. 2014; Fibrin-based biomaterials: modulation of macroscopic properties through rational design at the molecular level. Acta Biomater 10: 1502-1514.

Campos LS. 2004; Neurospheres: insights into neural stem cell biology. J Neurosci Res 78: 761-769.

Chambers SM, Fasano CA, Papapetrou EP, et al. 2009; Highly efficient neural conversion of human ES and iPS cells by dual inhibition of SMAD signaling. Nat Biotechnol 27: 275-280.

Colombo E, Giannelli SG, Galli R, et al. 2006; Embryonic stem-derived versus somatic neural stem cells: a comparative analysis of their developmental potential and molecular phenotype. Stem Cells 24: 825-834.

Conti L, Pollard SM, Gorba T, et al. 2005; Niche-independent symmetrical self-renewal of a mammalian tissue stem cell. PLoS Biol 3: e283.

Davis H, Gascho C, Kiernan JA. 1975; Action of aprotinin on the survival of adult cerebellar neurons in organ culture. Acta Neuropathol 32: 359-362.

Dhara SK, Stice SL. 2008; Neural differentiation of human embryonic stem cells. J Cell Biochem 105: 633-640.

Elkin BS, Ilankovan Al, Morrison B 3rd. 2011; A detailed viscoelastic characterization of the $\mathrm{P} 17$ and adult rat brain. J Neurotrauma 28: 2235-2244.

Erceg S, Ronaghi M, Oria M, et al. 2010; Transplanted oligodendrocytes and motoneuron progenitors generated from human embryonic stem cells promote locomotor recovery after spinal cord transection. Stem Cells 28: 15411549 . 
Fang JD, Chou HC, Tung HH, et al. 2011; Endogenous expression of matriptase in neural progenitor cells promotes cell migration and neuron differentiation. J Biol Chem 286: 5667-5679.

Fujioka H, Dairyo Y, Yasunaga K, et al. 2012; Neural functions of matrix metalloproteinases: plasticity, neurogenesis, and disease, Biochem Res Int 2012: 789083.

Incitti T, Messina A, Bozzi Y, et al. 2014; Sorting of Sox1-GFP mouse embryonic stem cells enhances neuronal identity acquisition upon factor-free monolayer differentiation. Biores Open Access 3: 127-135.

Janmey PA, Winer JP, Weisel JW. 2009; Fibrin gels and their

clinical and bioengineering applications. J R Soc Interface

6: 1-10.

Kim DS, Jung SJ, Nam TS, et al. 2010; Transplantation of GABAergic neurons from ESCs attenuates tactile hypersensitivity following spinal cord injury. Stem Cells 28: 2099-2108.

Levi-Montalcini R, Angeletti PU. 1963; Essential role of the nerve growth factor in the survival and maintenance of dissociated sensory and sympathetic embryonic nerve cells in vitro. Dev Biol 6: 653-659.

Lindvall O, Kokaia Z. 2010; Stem cells in human neurodegenerative disorders - time for clinical translation? J Clin Invest 120: 29-40.

Lu P, Jones LL, Snyder EY, et al. 2003; Neural stem cells constitutively secrete neurotrophic factors and promote extensive host axonal growth after spinal cord injury. Exp Neurol 181: 115-129.

Lu P, Wang Y, Graham L, et al. 2012; Long-distance growth and connectivity of neural stem cells after severe spinal cord injury. Cell 150: 1264-1273.

Man AJ, Davis HE, Itoh A, et al. 2011; Neurite outgrowth in fibrin gels is regulated by substrate stiffness. Tissue Eng Part A 17: 2931-2942.

Martino MM, Briquez PS, Ranga A, et al. 2013; Heparinbinding domain of fibrin(ogen) binds growth factors and promotes tissue repair when incorporated within a synthetic matrix. Proc Natl Acad Sci U S A 110: $4563-4568$.

McDonald JW, Becker D, Holekamp TF, et al. 2004; Repair of the injured spinal cord and the potential of embryonic stem cell transplantation. J Neurotrauma 21: 383-393.

Mori $\mathrm{H}$, Ninomiya K, Kino-oka M, et al. 2006; Effect of neurosphere size on the growth rate of human neural stem/progenitor cells. J Neurosci Res 84: 1682-1691.

Okano H. 2010; Neural stem cells and strategies for the regeneration of the central nervous system. Proc Jpn Acad Ser B Phys Bilo Sci 86: 438-450.

Pego AP, Kubinova S, Cizkova D, et al. 2012; Regenerative medicine for the treatment of spinal cord injury: more than just promises? J Cell Mol Med 16: 2564-2582.

Petter-Puchner AH, Froetscher W, Krametter-Froetscher R, et al. 2007; The long-term neurocompatibility of human fibrin sealant and equine collagen as biomatrices in experimental spinal cord injury. Exp Toxicol Pathol 58 : $237-245$.

Sart S, Ma T, Li Y. 2014; Extracellular matrices decellularized from embryonic stem cells maintained their structure and signaling specificity. Tissue Eng Part A 20: 54-66.

Schense JC, Hubbell JA. 1999; Cross-linking exogenous bifunctional peptides into fibrin gels with factor XIIla. Bioconjug Chem 10: 75-81.

Sen A, Kallos MS, Behie LA. 2001; Effects of hydrodynamics on cultures of mammalian neural stem cell aggregates in suspension bioreactors. Ind Eng Chem Res 40: 5350-5357. 
Sheppard AM, Hamilton SK, Pearlman AL. 1991; Changes in the distribution of extracellular matrix components accompany early morphogenetic events of mammalian cortical development. J Neurosci 11: 3928-3942.

Shetty AK, Turner DA. 1998; In vitro survival and differentiation of neurons derived from epidermal growth factorresponsive postnatal hippocampal stem cells: inducing effects of brain-derived neurotrophic factor. J Neurobiol 35: 395-425.

Solozobova V, Wyvekens N, Pruszak J. 2012; Lessons from the embryonic neural stem cell niche for neural lineage differentiation of pluripotent stem cells. Stem Cell Rev 8: 813-829.

Sun W, Incitti T, Migliaresi C, et al. 2015; Viability and neuronal differentiation of neural stem cells encapsulated in silk fibroin hydrogel functionalized with an IKVAV peptide. J Tissue Eng Regen Med doi: 10.1002/term.2053.

Tonti GA, Mannello F, Cacci E, et al. 2009; Neural stem cells at the crossroads: MMPs may tell the way. Int J Dev Biol 53: 1-17.

Willerth SM, Arendas KJ, Gottlieb DI, et al. 2006; Optimization of fibrin scaffolds for differentiation of murine embryonic stem cells into neural lineage cells. Biomaterials 27: 5990-6003.

Wilson JL, Suri S, Singh A, et al. 2014; Single-cell analysis of embryoid body heterogeneity using microfluidic trapping array. Biomed Microdevices 16: 79-90.

Ying QL, Smith AG. 2003; Defined conditions for neural commitment and differentiation. Methods Enzymol 365: 327-341.

Ying QL, Stavridis M, Griffiths D, et al. 2003; Conversion of embryonic stem cells into neuroectodermal precursors in adherent monoculture. Nat Biotechnol 21: 183-186. 
a
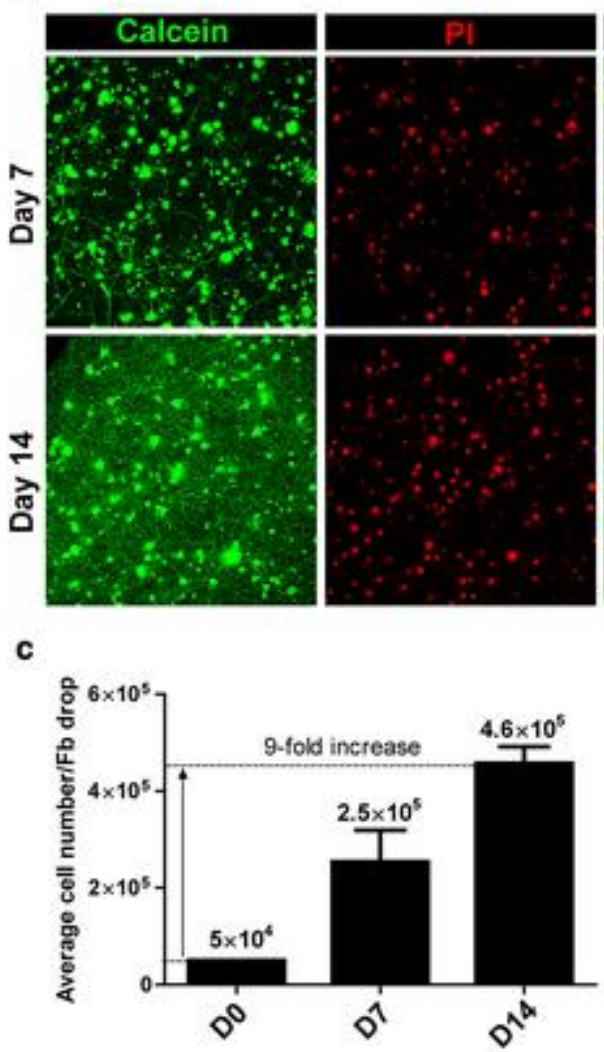

b
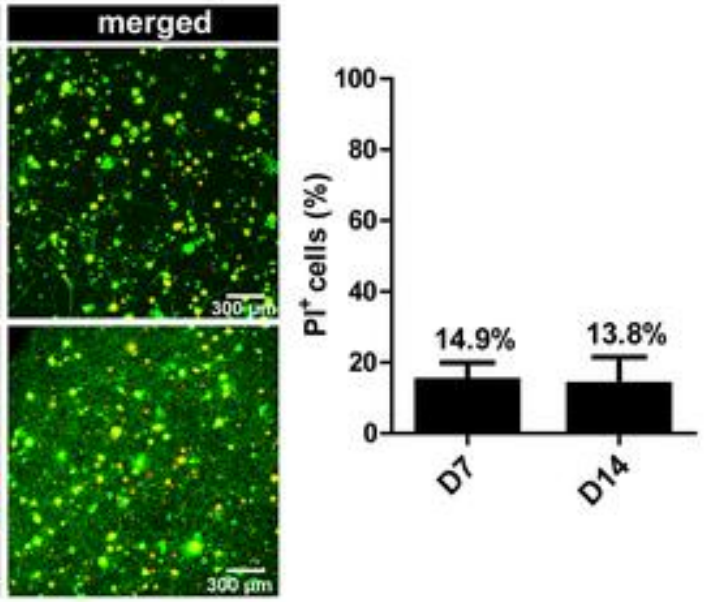

d

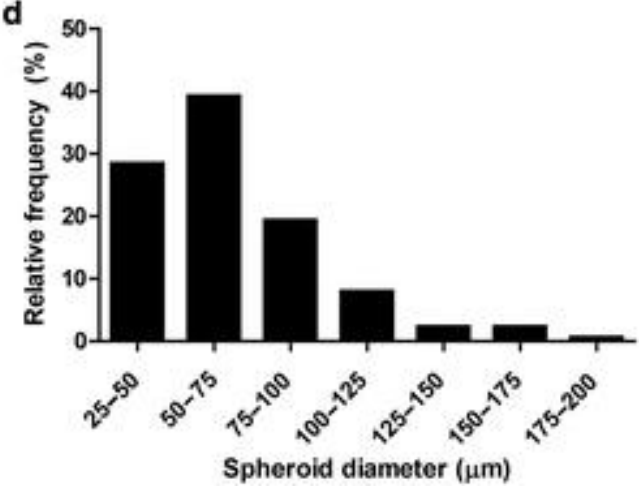

Figure 1 Cell viability, proliferation, and cellular spheroid diameter of mouse embryonic stem-neural stem/progenitor cell (mES-NSPCs) within fibrin (Fb) hydrogels. (a) Distribution of live and/or dead cells at day 7 and day 14 of culture; cell-Fb constructs were incubated with calcein AM and propidium iodide (PI) for detection of live and dead cells, respectively, and imaged by confocal laser scanning microscopy (CLSM); representative twodimensional projections of CLSM stack images covering a depth of $300 \mu \mathrm{m}$ are shown. (b) Quantitative analysis of cells incorporating $\mathrm{PI}\left(\mathrm{Pl}^{+}\right.$, non-viable cells) at day 7 (D7) and day ${ }_{14}$ (D14) of culture, as determined by flow cytometry ( $n=3$ independent experiments). (c) Total number of viable cells per Fb drop at day o (Do; upon cell embedment within $\mathrm{Fb}$ ), day 7 and day 14 of culture ( $n=3$ independent experiments). (d) Histogram of cellular spheroid (neurosphere) diameter distribution at day 14 of culture; analysis was performed in four Fb drops from two independent experiments. [Colour figure can be viewed at wileyonlinelibrary.com] 

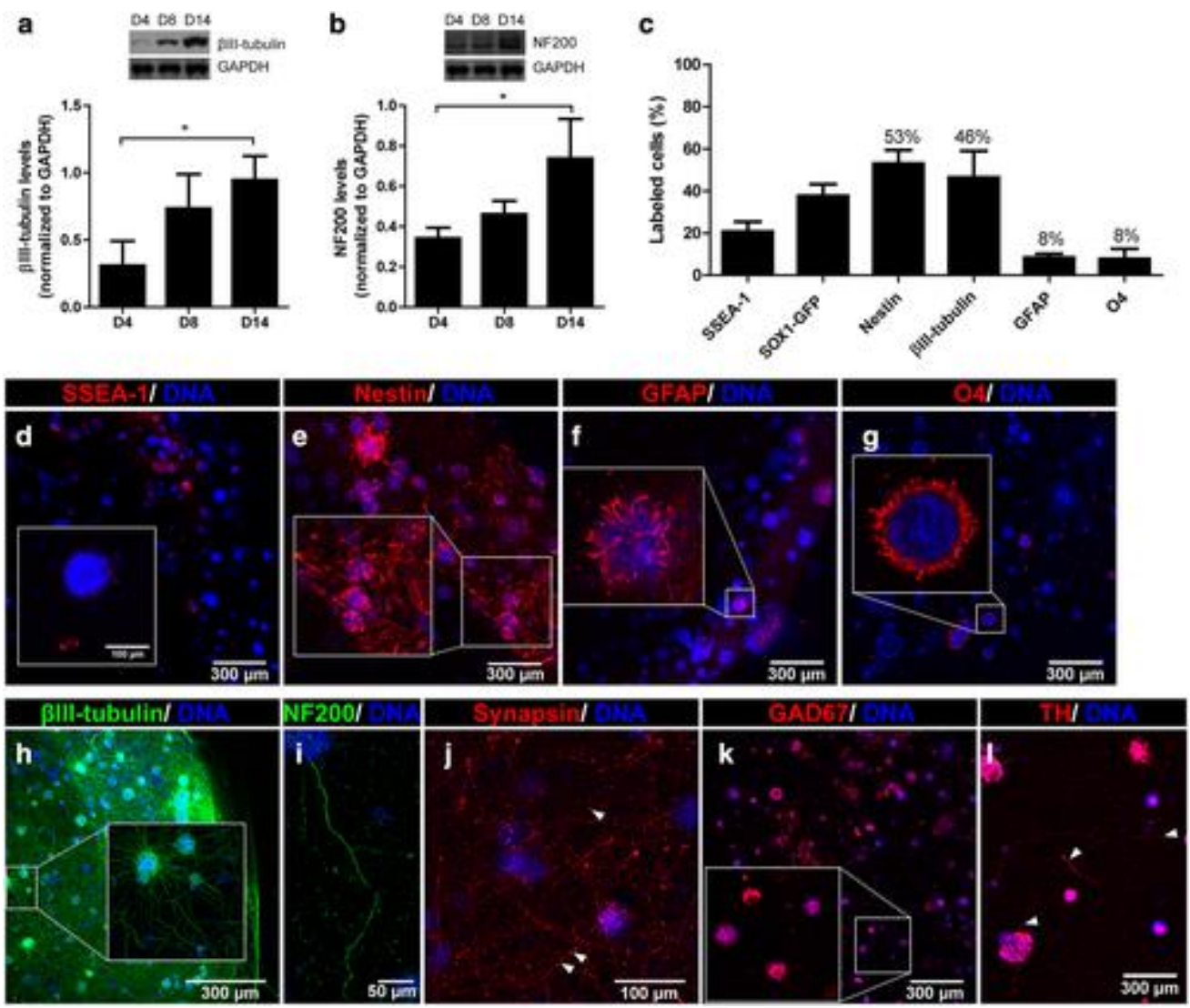

Figure 2. Phenotypic characterization of mouse embryonic stem-neural stem/progenitor cell (mES-NSPCs) within fibrin (Fb) hydrogels. Western blot analysis of (a) Blll-tubulin (developing and mature neurons) and (b) NF200 (mature neurons) expression over the culture period ( $n=3$ independent experiments). (c) Quantitative expression of stage-specific embryonic antigen 1 (SSEA-1; mouse embryonic stem cells), SOX1-green fluorescent protein (GFP) (early neuroectodermal marker), nestin (neural stem/progenitor cells), BIII-tubulin, glial fibrillary acidic protein (GFAP; astrocytes) and $\mathrm{O}_{4}$ (oligodendrocytes) at day ${ }_{14}$ (D14) as determined by flow cytometry ( $n=2$ independent experiments). Representative two-dimensional (2D) projections of confocal laser scanning microscopy (CLSM) stack images of cell/Fb constructs at day 14 processed for immunofluorescence labelling of (d) SSEA-1, (e) nestin, (f) GFAP, (g) O4, (h) Blll-tubulin, (i) NF200, (j) synapsin (synaptic vesicles), (k) GAD 67 (GABAergic phenotype) and (I) tyrosine hydroxylase ( $\mathrm{TH}$, dopaminergic and noradrenergic phenotype). GAPDH, glyceraldehyde-3-phosphate-dehydrogenase. [Colour figure can be viewed at wileyonlinelibrary.com] 

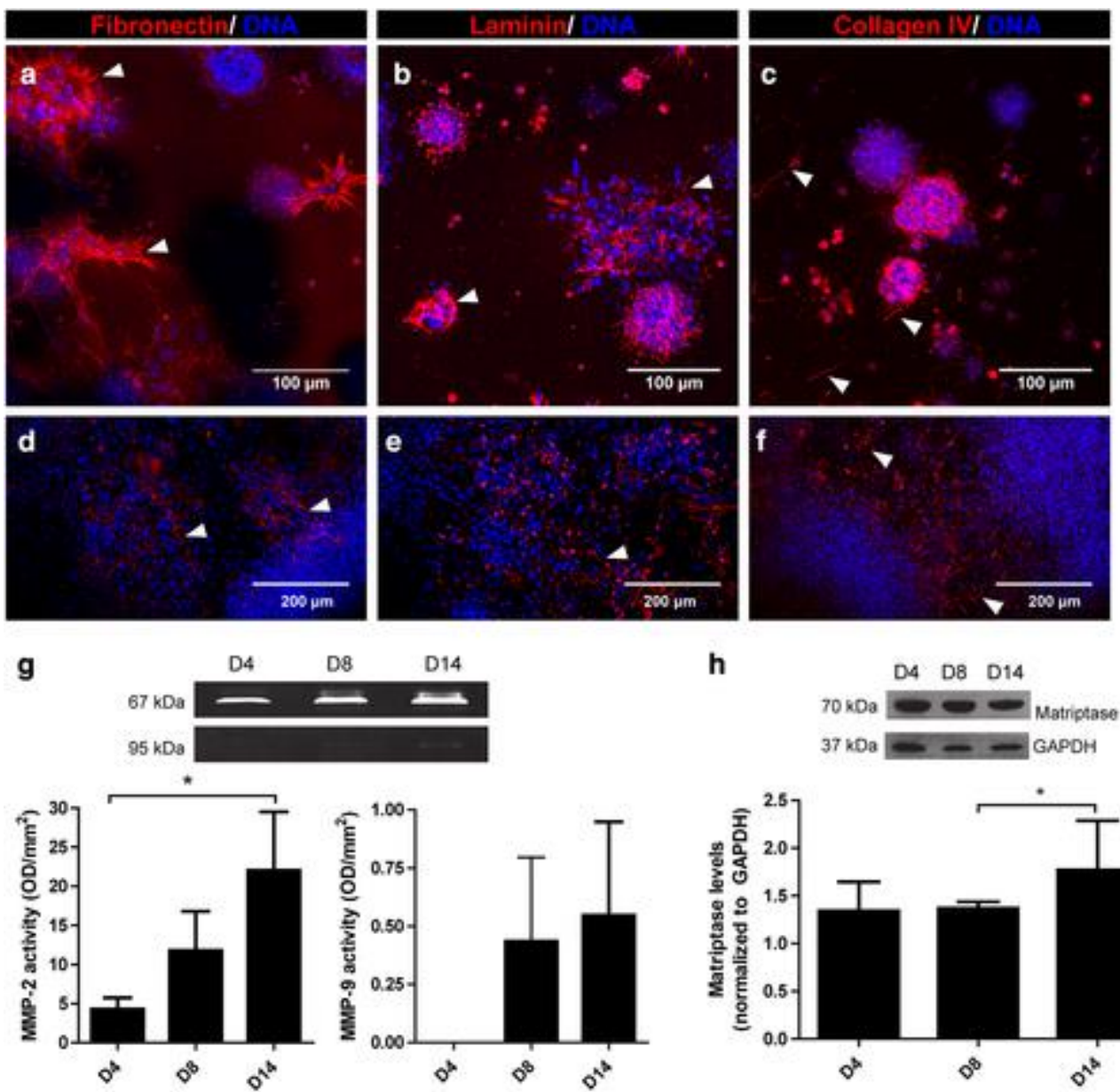

h
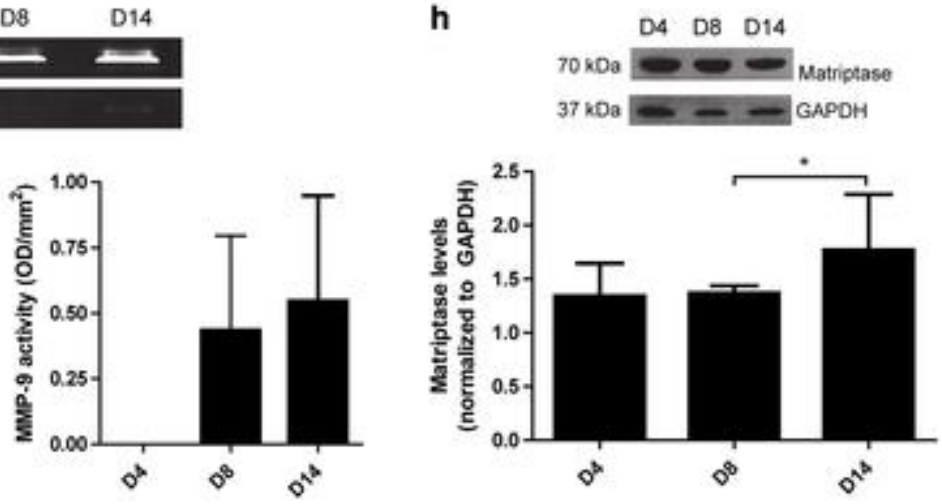

Figure 3. Characterization of mouse embryonic stem-neural stem/progenitor cell (mES-NSPC) culture in terms of deposition of extracellular matrix (ECM) proteins and proteolytic activity. Representative two-dimensional projections of confocal laser scanning microscopy stack images of cell-fibrin ( $\mathrm{Fb}$ ) constructs processed for immunofluorescence labelling of (a) fibronectin, (b) laminin and (c) collagen type IV, at day 14 of culture. (d-f) Immunofluorescent labelling of ES-NSPCs cultured on poly-d-lysine/laminin-coated glass coverslips, at the same time-point. (g) Activity of secreted matrix metalloproteinases (MMPs) as determined by gelatin zymography ( $n=3$ independent experiments; $\left.{ }^{*}<<0.05\right)$; ES-NSPCs embedded within Fb secrete matrix metalloproteinase (MMP)-2 and MMP- 9 , with MMP- 9 being detected at a later stage of culture; MMP-2 activity increased at day $14(n=3$ independent experiments; ${ }^{*} p<0.05$ ). (h) Western blot analysis of matriptase expression over the culture period, showing that ES-NSPCs within Fb endogenously express matriptase $\left(n=3\right.$ independent experiments; $\left.{ }^{*} p<0.05\right)$. [Colour figure can be viewed at wileyonlinelibrary.com] 
a

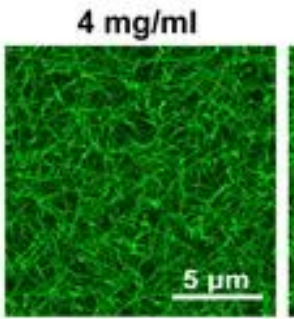

$6 \mathrm{mg} / \mathrm{ml}$

$8 \mathrm{mg} / \mathrm{ml}$

$10 \mathrm{mg} / \mathrm{ml}$
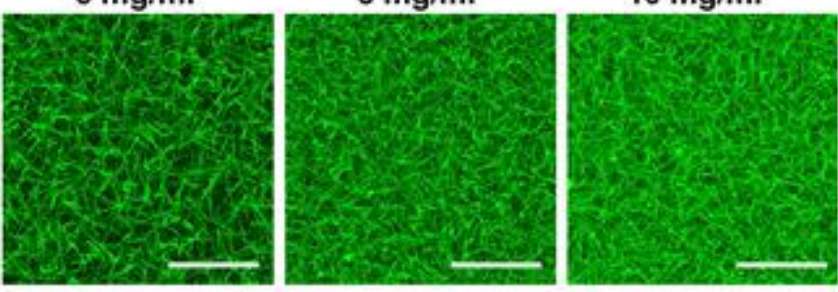

b
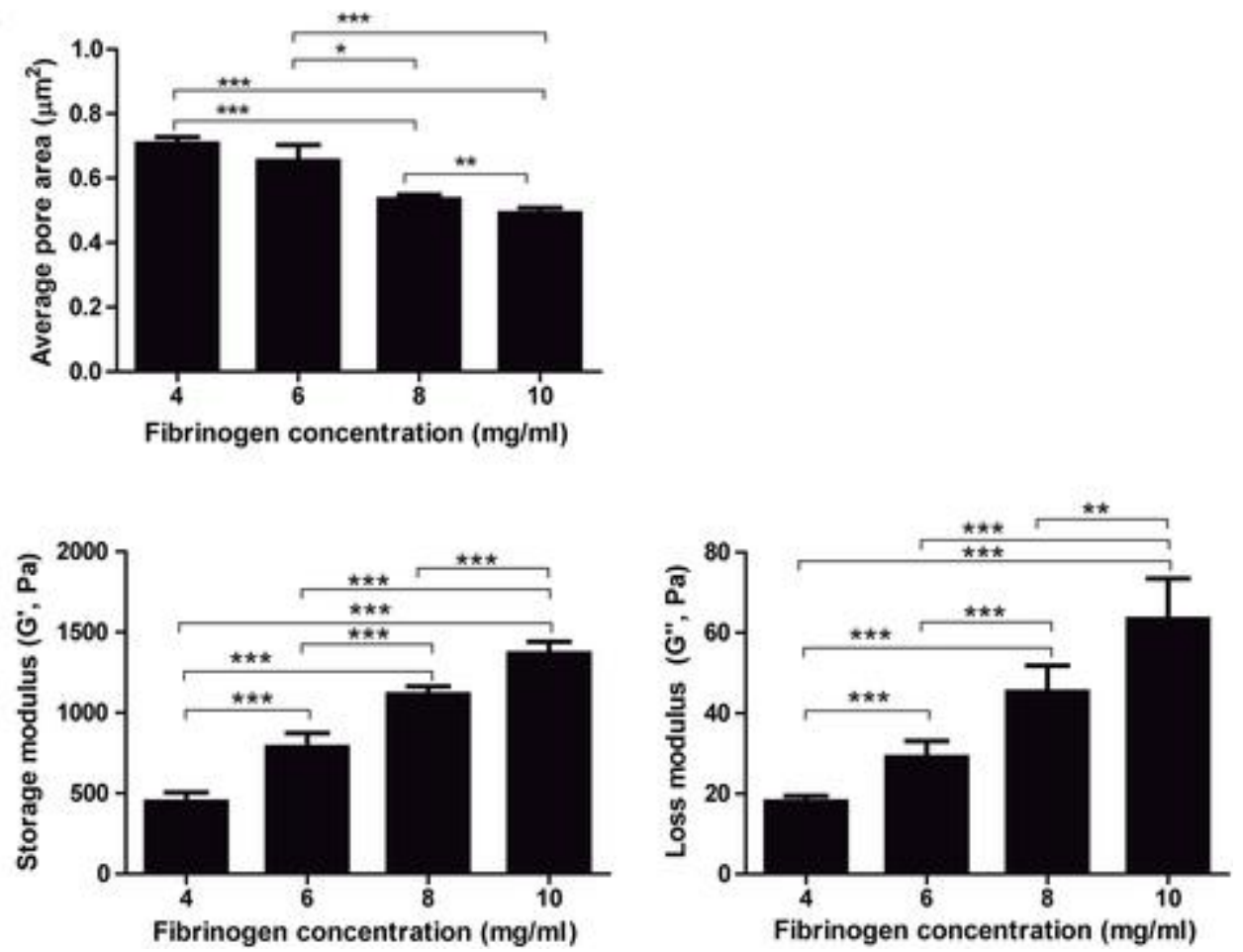

Figure 4. Effect of fibrinogen concentration on fibrin ( $\mathrm{Fb}$ ) hydrogels microstructure and stiffness. (a) Microstructure of $\mathrm{Fb}$ gels prepared with 4, 6, 8 or $10 \mathrm{mg} / \mathrm{ml}$ of fibrinogen spiked with Alexa Fluor 488-labelled fibrinogen; representative two-dimensional (2D) projections of confocal laser scanning microscopy (CLSM) stack images covering a depth of $10 \mu \mathrm{m}$ are shown. (b) Average pore area of $\mathrm{Fb}$ hydrogels, as determined by image analysis of the $2 \mathrm{D}$ projected CLSM stacks $\left(n=4 ;{ }^{*} p<0.05\right.$ ). (c) Storage modulus ( $\left.G^{\prime}\right)$ and loss modulus ( $G$ ") of Fb hydrogels, as assessed by rheological analysis ( $n=6$ independent experiments; $* p<0.05 ; * * p<0.01 ; * * * p<$ 0.005). [Colour figure can be viewed at wileyonlinelibrary.com] 

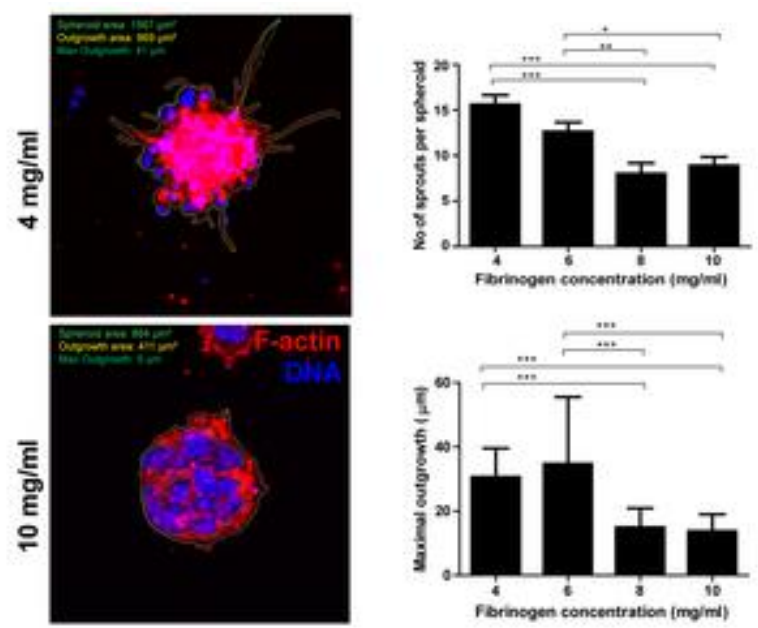

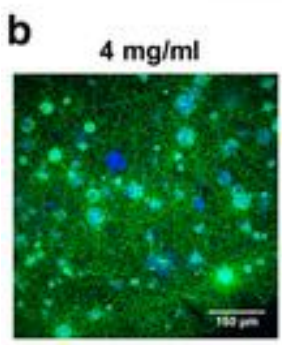

C

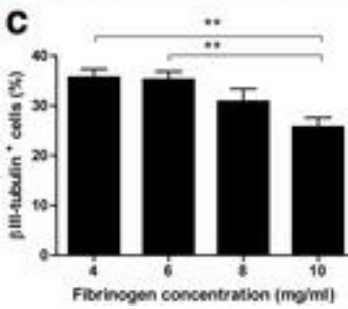

$6 \mathrm{mg} / \mathrm{ml}$

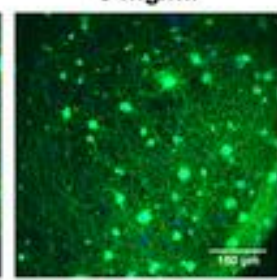

d

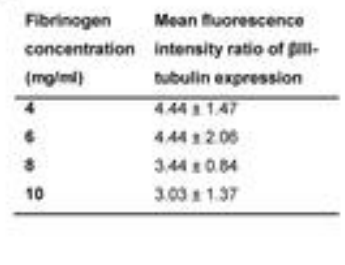

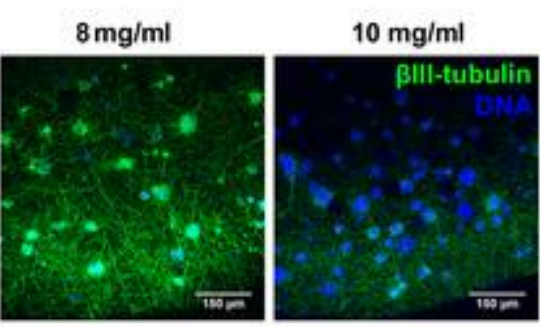

e

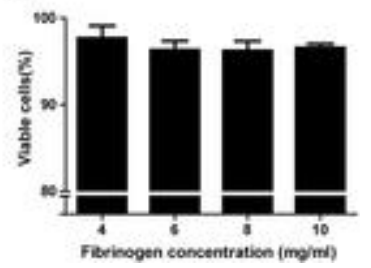

Figure 5. Effect of fibrinogen concentration on mouse embryonic stem-neural stem/progenitor cell (mES-NSPC) outward migration, viability and neuronal differentiation within fibrin (Fb) hydrogels. (a) Representative twodimensional (2D) projections of confocal laser scanning microscopy (CLSM) stack images of cell-Fb constructs processed for F-actin/DNA staining at day 4 of culture; images for Fb hydrogels prepared with $4 \mathrm{mg} / \mathrm{ml}$ or 10 $\mathrm{mg} / \mathrm{ml}$ of fibrinogen are shown. Neurite extension/outward migration from cellular spheroids was quantified by image analysis; bar graphs depict the number of sprouts (above) and the maximal outgrowth (below) per spheroid ( $n=10$ spheroids from two replicate cultures; $* p<0.05 ; * * p<0.01 ; * * * p<0.005$ ). (b) Neuronal network formed within Fb hydrogels at day 14 of culture, as assessed by immunofluorescence labelling of $\beta$ III-tubulin; representative $2 \mathrm{D}$ projections of CLSM stack images of cell-Fb constructs covering a depth of $100 \mu \mathrm{m}$ are shown. (c-d) Flow cytometry analysis of $\beta$ III-tubulin expression at day 14 of culture. (c) Percentage of positive cells, showing a decrease in the percentage of $\beta$ III-tubulin+ cells when increasing the fibrinogen concentration from $4 / 6$ $\mathrm{mg} / \mathrm{ml}$ to $10 \mathrm{mg} / \mathrm{mL}$ ( $n=4-6$ independent experiments; ** $p<0.01)$; (d) the analysis of the mean fluorescence intensity ratio of the histograms also suggest a lower expression of $\beta$ III-tubulin in these Fb gels. (e) Percentage of viable cells at day 14 of culture using Trypan Blue dye exclusion method ( $n=4-6$ independent experiments).

[Colour figure can be viewed at wileyonlinelibrary.com] 
a
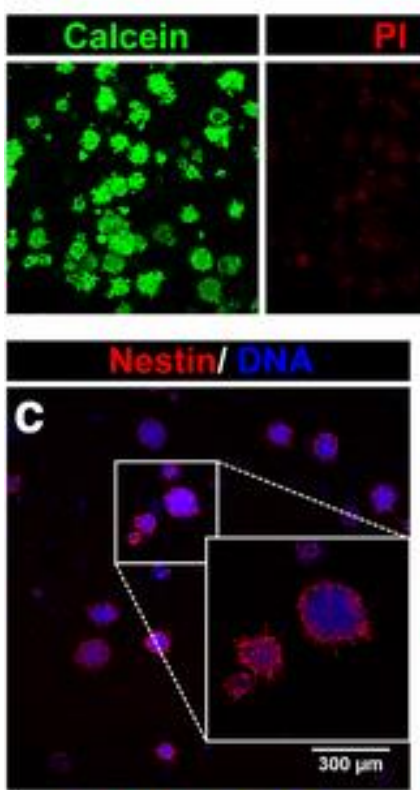

Laminin/

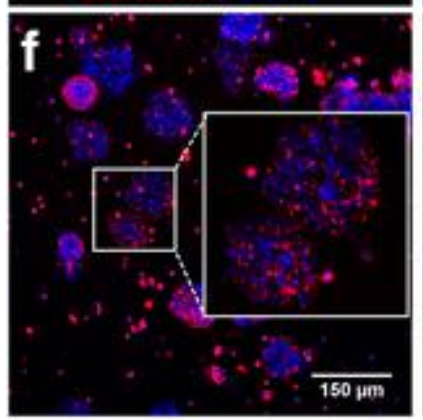

b
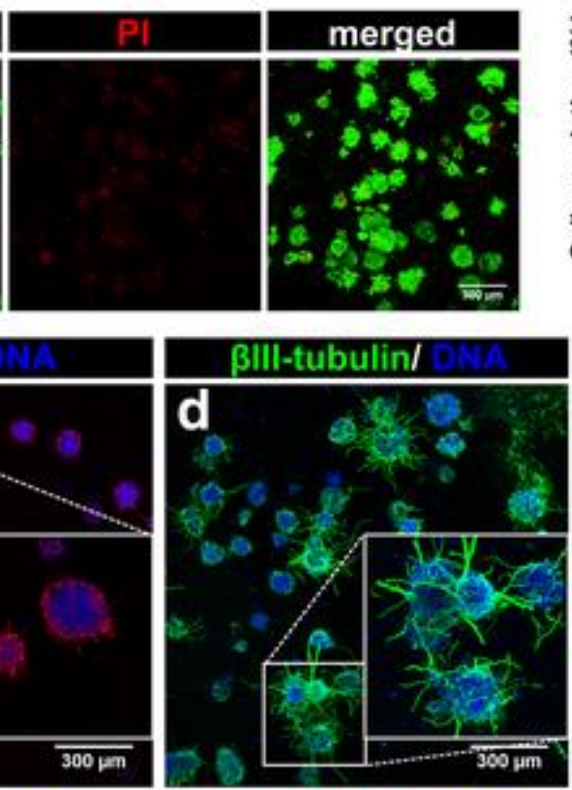

Fibronectinl

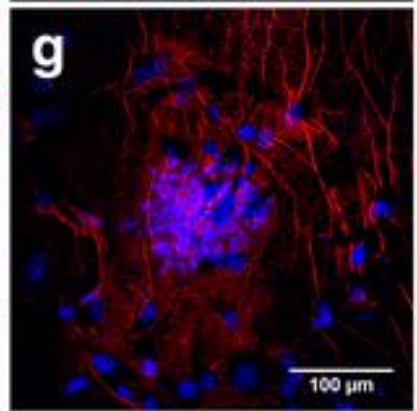

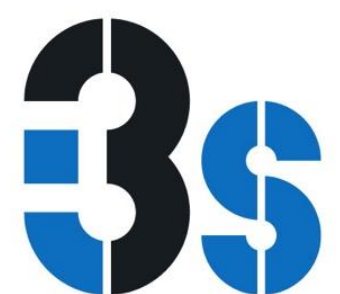
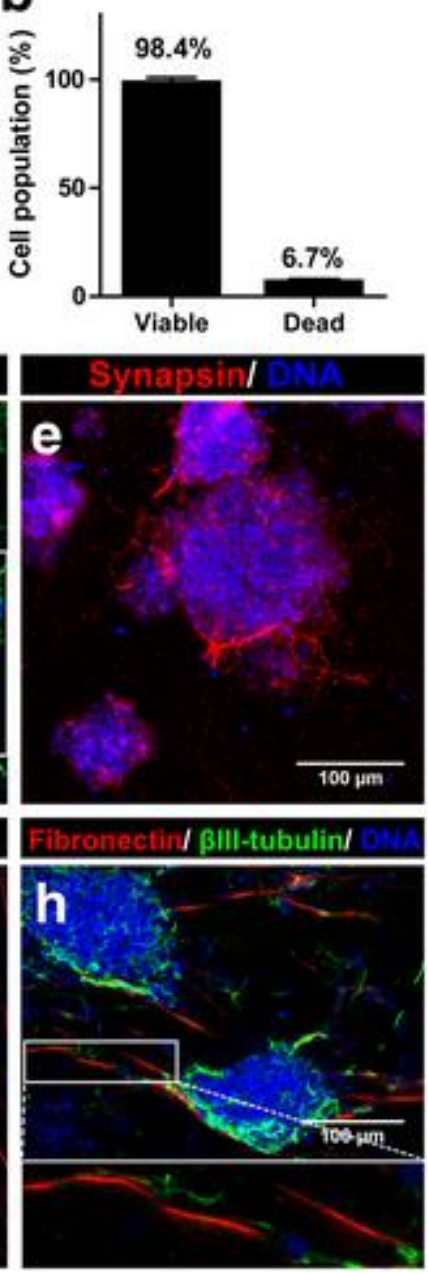

Figure 6. Cell viability, phenotype and extracellular matrix (ECM) deposition of human embryonic stem-neural stem/progenitor cells (ES-NSPCs) cultured within fibrin (Fb) hydrogels. (a) Distribution of live and/or dead cells at day 14 of cell culture; cell-Fb constructs were incubated with calcein AM and propidium iodide (PI) for detection of live and dead cells, respectively, and imaged by confocal laser scanning microscopy (CLSM); representative twodimensional (2D) projections of CLSM stack images covering a depth of $150 \mu \mathrm{m}$ are shown. (b) Quantitative analysis of live and dead cells at day 14, as determined by flow cytometry ( $n=3$ independent experiments). (c-h) Representative $2 \mathrm{D}$ projections of CLSM stack images of cell/Fb constructs processed for immunofluorescence labelling of (c) nestin, (d) BIII-tubulin, (e) synapsin (synaptic vesicles), ( $f$ ) laminin, (g) fibronectin, and (h) fibronectin and $\beta$ III-tubulin; inset shows a single confocal image ( $0.17 \mu \mathrm{m}$ in depth) demonstrating close association of fibronectin fibrils with neurites. Images $(c-g)$ correspond to day 14 of cell culture and image (h) to day 21 . [Colour figure can be viewed at wileyonlinelibrary.com] 


\section{Supplementary Materials and Methods}

Culture of mES-NSPCs on laminin-coated glass coverslips under neuronal differentiation conditions

Glass coverslips previously coated with $10 \mu \mathrm{g} / \mathrm{mL}$ of poly-D-lysine (P7280, Sigma) were incubated overnight with 5 $\mu \mathrm{g} / \mathrm{mL}$ of laminin (L2020, Sigma). After cell dissociation, cell suspension was transferred to poly-D-lysine/laminin-

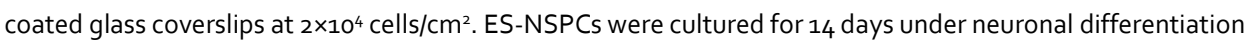
conditions, following the same protocol described for neuronal differentiation of ES-NSPCs within Fb gels (for detailed description see section 2.2 of the manuscript).

Cell viability and total cell number

For qualitative cell viability analysis, cell-Fb constructs were sequentially incubated with $4 \mu \mathrm{M}$ calcein $\mathrm{AM}$ (Invitrogen; 30 min at $37^{\circ} \mathrm{C}$ ) and $6 \mu \mathrm{M}$ propidium iodide $\left(\mathrm{PI} ;\right.$ Sigma; 10 min at $37^{\circ} \mathrm{C}$ ), for detection of live and dead cells, respectively. After incubation, samples were washed twice with PBS, transferred to cell culture media, and immediately observed under the confocal laser scanning microscope (CLSM; Leica TCS SP 5 II). Quantitative analysis of cell viability was performed in a pool of six $\mathrm{Fb}$ drops after cell isolation from the cell-Fb constructs, as described in Materials and Methods section. Cell number per drop was determined using a Neubauer chamber and the percentage of viable cells determined using Trypan Blue dye exclusion method or by flow cytometry. For flow cytometry analysis single cell suspensions were incubated with $67 \mathrm{nM}$ calcein $\mathrm{AM}\left(20 \mathrm{~min}\right.$ at $37^{\circ} \mathrm{C}$ ) or with $6 \mu \mathrm{M} \mathrm{PI}$ (10 $\mathrm{min}$ at $37^{\circ} \mathrm{C}$ ) to label live and dead cells, respectively. Cells were finally washed $3 x$, suspended in FACS buffer and analysed by flow cytometry, unlabeled cells were used as negative control. Representative histograms are represented in Figure $\mathrm{S}_{3} \mathrm{~A}$. The average cell number per $\mathrm{Fb}$ drop was determined dividing the total number of viable cells counted using the Neubauer chamber by the number of $\mathrm{Fb}$ drops.

\section{5-Bromo-2'-deoxyuridine (BrdU) assay}

The percentage of proliferative cells was assessed by immunocytometry detection of BrdU incorporated into cells synthesizing DNA. BrdU (Sigma) was added to the cell culture medium of six replicate Fb drops at the final concentration of $50 \mu \mathrm{M}$, and ES-NSPCs kept in culture for additional $18 \mathrm{~h}$. Cells were isolated from the gels as described, fixed in $1 \%(\mathrm{w} / \mathrm{v})$ paraformaldehyde (PFA; $20 \mathrm{~min})$, permeabilized with $0.2 \%(\mathrm{v} / \mathrm{v})$ Triton X-100 (10 min at $4^{\circ} \mathrm{C}$ ) and further exposed to $2 \mathrm{M} \mathrm{HCl}$ for $20 \mathrm{~min}$. Cells were subsequently incubated in blocking buffer [PBS buffer containing $5 \%$ normal goat serum (NGS, Biosource) and $0.1 \%$ (w/v) saponin] for $20 \mathrm{~min}$ followed by incubation with anti-BrdU ( $\mathrm{V} 450$-conjugated anti-BrdU antibody, 560810, BD Horizon; $8 \mu \mathrm{g} / \mathrm{mL}$ ) for $30 \mathrm{~min}$. Cells were finally washed $3 \times$ and suspended in FACS buffer containing sodium azide for immunocytometry analysis (FACSCanto ${ }^{\mathrm{TM}} \mathrm{II}$, BD Biosciences). Samples not exposed to BrdU but processed in parallel for immunodetection of $\mathrm{BrdU}$ were used as negative control. Representative histograms are shown in Figure $\mathrm{S}_{4} \mathrm{C}$.

\section{Gelatin zymography}

MMP activity in conditioned media of mES-NSPC cultures before and after embedment within Fb was analysed by gelatin zymography, as previously described (Cardoso et al., 2014). For this purpose, media was collected at day 5 of the neural commitment protocol and after 4, 8, and 14 days of ES-NSPC culture within Fb. Total protein was determined and $20 \mu \mathrm{g}$ of total protein loaded per lane. MMP activity was analysed using Quantity One software (BioRad). Data presented correspond to three independent experiments. MMP activity was analysed using Quantity One software (BioRad), and interpreted based on the literature (Frankowski et al., 2012).

\section{Western Blot analysis}

Western blot analysis was performed on protein extracts of mES-NSPCs, before and after cell embedment within Fb. For this purpose, cold RIPA buffer was added to dissociated ES-NSCs at day 5 of neural commitment or added directly to a pool of six cell/Fb constructs collected at day 4,8 , and 14 of culture. The constructs were sonicated, centrifuged at $13000 \times \mathrm{g}\left(10 \mathrm{~min}\right.$ at $\left.4^{\circ} \mathrm{C}\right)$, and protein concentration in the supernatant fractions determined by the Dc protein assay (BioRad). Protein extracts ( $5 \mu \mathrm{g}$ for matriptase expression, and $20 \mu \mathrm{g}$ for $\beta$ Ill-tubulin and NF200 expression) were incubated at $95^{\circ} \mathrm{C}$ for $5 \mathrm{~min}$ and subjected to a $10 \%$ or $4-12 \%$ SDS-PAGE. After SDS/PAGE separation the proteins were transferred to a nitrocellulose membrane (GE Healthcare) and blocked in TBS-T 
buffer containing $5 \%(\mathrm{w} / \mathrm{v})$ skim milk or $5 \%(\mathrm{w} / \mathrm{v})$ bovine serum albumin for $1 \mathrm{~h}$. The membranes were then incubated with rabbit polyclonal anti-matriptase (sc-48830, Santa Cruz Technologies; 1:2000), rabbit monoclonal anti-BIII-tubulin (MRB-435P; Covance; 1:5000), rabbit polyclonal anti-NF200 (AB8135, Abcam; 1:2000), and mouse monoclonal anti-GAPDH ( $5 \mathrm{G}_{4}-6 \mathrm{C}_{5}$, HyTest; $1: 40000$ ) overnight at $4^{\circ} \mathrm{C}$. After rinsing with TBS-T buffer membranes were incubated for $1 \mathrm{~h}$ with horseradish peroxidase-conjugated secondary antibodies and the blots developed with horseradish peroxidase-reactive chemiluminescence reagents (GE Healthcare). After exposure to autoradiographic film, the relative density of the protein band was further analysed with Quantity One software (BioRad). 
Table S1 - Primary and secondary antibodies as well as isotype controls used for immunocytometry studies.

\begin{tabular}{|c|c|c|c|c|c|c|c|c|}
\hline Target & $\begin{array}{l}\text { Blocking } \\
\text { solution }\end{array}$ & $\begin{array}{l}\text { Primary } \\
\text { Antibody }\end{array}$ & $\begin{array}{l}\text { Isotype } \\
\text { control }\end{array}$ & Dilution & $\begin{array}{l}\text { Origin and } \\
\text { product number }\end{array}$ & $\begin{array}{l}\text { Secondary } \\
\text { Antibody }\end{array}$ & Dilution & $\begin{array}{l}\text { Origin and } \\
\text { product number }\end{array}$ \\
\hline Mouse ES cells & $\begin{array}{l}5 \%(\mathrm{v} / \mathrm{v}) \\
\text { NGS in } \\
\text { PBS }\end{array}$ & $\begin{array}{l}\text { Mouse } \\
\text { monoclonal } \\
\text { anti-SSEA-1 }\end{array}$ & - & $1: 100$ & $\begin{array}{l}\text { SantaCruz } \\
\text { Biotechnology sc- } \\
21702\end{array}$ & $\begin{array}{l}\text { Goat anti- } \\
\text { mouse IgM- } \\
\text { PE }\end{array}$ & $1: 100$ & $\begin{array}{l}\text { Santa Cruz } \\
\text { Biotechnology sc- } \\
3768\end{array}$ \\
\hline NSPCs & $\begin{array}{l}5 \%(\mathrm{v} / \mathrm{v}) \\
\text { NGS and } \\
0.1 \%(\mathrm{w} / \mathrm{v})\end{array}$ & $\begin{array}{l}\text { Mouse } \\
\text { monoclonal } \\
\text { anti-nestin }\end{array}$ & - & $1: 100$ & $\begin{array}{l}\text { Chemicon } \\
\text { MAB353 }\end{array}$ & $\begin{array}{l}\text { Goat anti- } \\
\text { mouse } \\
\text { IgG1-PE }\end{array}$ & $1: 100$ & $\begin{array}{l}\text { Santa Cruz } \\
\text { Biotechnology sc- } \\
3764\end{array}$ \\
\hline $\begin{array}{l}\text { Developing and } \\
\text { mature neurons }\end{array}$ & $\begin{array}{l}\text { saponin in } \\
\text { PBS }\end{array}$ & $\begin{array}{l}\text { Mouse } \\
\text { monoclonal } \\
\text { anti- } \beta \text { III } \\
\text { tubulin }\end{array}$ & - & $1: 500$ & $\begin{array}{l}\text { Covance MMS- } \\
435 \mathrm{P}\end{array}$ & $\begin{array}{l}\text { Goat anti- } \\
\text { mouse IgG- } \\
\text { APC }\end{array}$ & $1: 100$ & $\begin{array}{l}\text { Santa Cruz } \\
\text { Biotechnology sc- } \\
3818\end{array}$ \\
\hline Astrocytes & & $\begin{array}{l}\text { Alexa Fluor } \\
647 \text { mouse } \\
\text { anti-GFAP }\end{array}$ & $\begin{array}{l}\text { Alexa } \\
\text { Fluor } 647 \\
\text { Mouse } \\
\text { IgG2b }\end{array}$ & $1: 100$ & $\begin{array}{l}\text { BD BioSciences } \\
561470(\mathrm{Ab}) \\
\text { BD BioSciences } \\
558713 \text { (Isotype) }\end{array}$ & - & - & - \\
\hline Oligodendrocytes & $\begin{array}{l}10 \%(\mathrm{v} / \mathrm{v}) \\
\text { NGS in } \\
\text { PBS }\end{array}$ & $\begin{array}{l}\text { Mouse } \\
\text { monoclonal } \\
\text { anti-O4 }\end{array}$ & - & $1: 50$ & $\begin{array}{l}\text { Chemicon } \\
\text { MAB345 }\end{array}$ & $\begin{array}{l}\text { Goat anti- } \\
\text { mouse IgM- } \\
\text { PE }\end{array}$ & $1: 100$ & $\begin{array}{l}\text { Santa Cruz } \\
\text { Biotechnology sc- } \\
3768\end{array}$ \\
\hline
\end{tabular}

NGS, normal goat serum; SSEA-1, stage-specific embryonic antigen 1; GFAP, glial fibrillary acidic protein. 
Table S2 - Primary and secondary antibodies used for immunocytochemistry studies.

\begin{tabular}{|c|c|c|c|c|c|c|c|}
\hline Target & Blocking solution & $\begin{array}{l}\text { Primary } \\
\text { Antibody }\end{array}$ & Dilution & $\begin{array}{l}\text { Origin and } \\
\text { product number }\end{array}$ & $\begin{array}{l}\text { Secondary } \\
\text { Antibody }\end{array}$ & Dilution & $\begin{array}{l}\text { Origin and product } \\
\text { number }\end{array}$ \\
\hline \multicolumn{8}{|l|}{ Cellular Markers } \\
\hline Mouse ES cells & $\begin{array}{l}5 \%(v / v) \text { NGS in } \\
\text { PBS }\end{array}$ & $\begin{array}{l}\text { Mouse } \\
\text { monoclonal } \\
\text { anti-SSEA-1 }\end{array}$ & $1: 100$ & $\begin{array}{l}\text { SantaCruz } \\
\text { Biotechnology sc- } \\
21702\end{array}$ & \multirow{3}{*}{$\begin{array}{l}\text { Alexa Fluor } \\
594 \text { goat } \\
\text { anti-mouse } \\
\text { lgG }\end{array}$} & $1: 1000$ & Invitrogen A11020 \\
\hline NSPCs & $\begin{array}{l}5 \%(v / v) \text { NGS in } \\
\text { PBS containing } \\
0.05 \%(v / v) \text { Tween- }\end{array}$ & $\begin{array}{l}\text { Mouse } \\
\text { monoclonal } \\
\text { anti-nestin }\end{array}$ & $1: 100$ & $\begin{array}{l}\text { Chemicon } \\
\text { MAB353 }\end{array}$ & & & \\
\hline & 20 & $\begin{array}{l}\text { Mouse } \\
\text { monoclonal } \\
\text { anti-nestin } \\
\text { (human) }\end{array}$ & $1: 200$ & $\begin{array}{l}\text { Chemicon } \\
\text { AB22035 }\end{array}$ & & & \\
\hline \multirow[t]{2}{*}{$\begin{array}{l}\text { Developing and } \\
\text { mature neurons }\end{array}$} & $\begin{array}{l}5 \%(\mathrm{v} / \mathrm{v}) \mathrm{HS} \\
\text { and } 3 \%(\mathrm{v} / \mathrm{v}) \\
\mathrm{BSA} \text { in PBS } \\
\text { containing } 0.05 \% \\
(\mathrm{v} / \mathrm{v}) \text { Tween-20 }\end{array}$ & $\begin{array}{l}\text { Rabbit } \\
\text { monoclonal } \\
\text { anti-ßIII } \\
\text { tubulin }\end{array}$ & $1: 500$ & $\begin{array}{l}\text { Chemicon } \\
\text { AB18207 }\end{array}$ & $\begin{array}{l}\text { Alexa Fluor } \\
647 \text { donkey } \\
\text { anti-rabbit } \\
\text { lgG }\end{array}$ & $1: 1000$ & Invitrogen A11070 \\
\hline & $\begin{array}{l}5 \%(v / v) B S A \text { in } \\
\text { PBS }\end{array}$ & $\begin{array}{l}\text { Mouse } \\
\text { monoclonal } \\
\text { anti-ßIII } \\
\text { tubulin }\end{array}$ & $1: 500$ & $\begin{array}{l}\text { Covance MMS- } \\
435 \mathrm{P}\end{array}$ & $\begin{array}{l}\text { Alexa Fluor } \\
488 \text { donkey } \\
\text { anti-mouse } \\
\text { lgG }\end{array}$ & $1: 1000$ & Invitrogen A21202 \\
\hline Astrocytes & & $\begin{array}{l}\text { Rabbit } \\
\text { polyclonal } \\
\text { anti-GFAP }\end{array}$ & $1: 500$ & DAKO Z0334 & $\begin{array}{l}\text { Alexa Fluor } \\
647 \text { donkey } \\
\text { anti-rabbit } \\
\text { IgG }\end{array}$ & $1: 1000$ & Invitrogen A11070 \\
\hline Oligodendrocytes & $\begin{array}{l}5 \%(v / v) \text { NGS in } \\
\text { PBS }\end{array}$ & $\begin{array}{l}\text { Mouse } \\
\text { monoclonal } \\
\text { anti-O4 }\end{array}$ & $1: 100$ & $\begin{array}{l}\text { Chemicon } \\
\text { MAB345 }\end{array}$ & $\begin{array}{l}\text { Alexa Fluor } \\
594 \text { goat } \\
\text { anti-mouse } \\
\text { IgG }\end{array}$ & $1: 1000$ & Invitrogen A11020 \\
\hline Mature neurons & $\begin{array}{l}5 \%(v / v) \text { NGS in } \\
\text { PBS containing } \\
0.05 \%(v / v) \text { Tween- } \\
20\end{array}$ & $\begin{array}{l}\text { Rabbit } \\
\text { polyclonal } \\
\text { anti-NF200 }\end{array}$ & $1: 1000$ & $\begin{array}{l}\text { Chemicon } \\
\text { AB8135 }\end{array}$ & $\begin{array}{l}\text { Alexa Fluor } \\
647 \text { donkey } \\
\text { anti-rabbit } \\
\text { IgG }\end{array}$ & $1: 1000$ & Invitrogen A11070 \\
\hline $\begin{array}{l}\text { Synapsin I, } \\
\text { phosphoproteins } \\
\text { associated to } \\
\text { synaptic vesicles }\end{array}$ & $\begin{array}{l}10 \%(v / v) \text { NGS in } \\
\text { PBS }\end{array}$ & $\begin{array}{l}\text { Rabbit } \\
\text { polyclonal } \\
\text { anti-synapsin } \\
\text { I }\end{array}$ & $1: 1000$ & $\begin{array}{l}\text { Chemicon } \\
\text { AB1543P }\end{array}$ & & & \\
\hline $\begin{array}{l}\text { GABAergic } \\
\text { neurons }\end{array}$ & & $\begin{array}{l}\text { Goat } \\
\text { polyclonal } \\
\text { anti-GAD67 }\end{array}$ & $1: 200$ & $\begin{array}{l}\text { Santa Cruz } \\
\text { Biotechnology sc- } \\
7512\end{array}$ & $\begin{array}{l}\text { Alexa Fluor } \\
660 \text { donkey } \\
\text { anti-goat } \\
\text { IgG }\end{array}$ & $1: 1000$ & Invitrogen A21983 \\
\hline $\begin{array}{l}\text { Dopaminergic and } \\
\text { noradrenergic } \\
\text { neurons }\end{array}$ & & $\begin{array}{l}\text { Rabbit } \\
\text { polyclonal } \\
\text { anti-tyrosine } \\
\text { hydroxylase }\end{array}$ & $1: 500$ & Chemicon AB152 & $\begin{array}{l}\text { Alexa Fluor } \\
647 \text { donkey } \\
\text { anti-rabbit } \\
\text { IgG }\end{array}$ & $1: 1000$ & Invitrogen A11070 \\
\hline
\end{tabular}




\begin{tabular}{|c|c|c|c|c|c|c|c|}
\hline \multicolumn{8}{|c|}{ ECM markers } \\
\hline \multirow[t]{4}{*}{ Fibronectin } & $5 \%(v / v) B S A$ in & Rabbit & $1: 100$ & Sigma-Aldrich & \multirow{7}{*}{$\begin{array}{l}\text { Alexa Fluor } \\
647 \text { donkey } \\
\text { anti-rabbit } \\
\operatorname{lgG}\end{array}$} & \multirow[t]{7}{*}{$1: 1000$} & \multirow[t]{7}{*}{ Invitrogen A11070 } \\
\hline & PBS & polyclonal & & F3648 & & & \\
\hline & & anti- & & & & & \\
\hline & & fibronectin & & & & & \\
\hline \multirow[t]{3}{*}{ Laminin } & $1 \%(\mathrm{v} / \mathrm{v}) \mathrm{BSA}$ and & Rabbit & $1: 50$ & Sigma-Aldrich & & & \\
\hline & $4 \%(v / v) F B S$ in & polyclonal & & L9393 & & & \\
\hline & PBS & anti-laminin & & & & & \\
\hline \multirow[t]{4}{*}{ Collagen IV } & $5 \%(v / v) B S A$ in & Goat & $1: 50$ & Chemicen AB769 & Alexa Fluor & $1: 1000$ & Invitrogen A21983 \\
\hline & PBS & polyclonal & & & 660 donkey & & \\
\hline & & anti-collagen & & & anti-goat & & \\
\hline & & IV & & & $\operatorname{lgg}$ & & \\
\hline
\end{tabular}

HS, horse serum; NGS, normal goat serum; FBS, fetal bovine serum; BSA, bovine serum albumine; SSEA-1, stage specific embrxonic antigen 1 ; GFAP, glial fibrillary acidic protein; NF200, neurofilament 200; GAD67, glutamic acid decarboxylase 67.

\section{Supplementary References}

Cardoso AP, Pinto ML, Pinto AT, Oliveira MI, Pinto MT, Goncalves R, et al. 2014, Macrophages stimulate gastric and colorectal cancer invasion through EGFR Y(1086), c-Src, Erk1/2 and Akt phosphorylation and smallGTPase activity, Oncogene, 33: 2123-33.

Frankowski H, Gu YH, Heo JH, Milner R, Del Zoppo GJ. 2012, Use of gel zymography to examine matrix metalloproteinase (gelatinase) expression in brain tissue or in primary glial cultures, Methods Mol Biol, 814: 22133. 
A

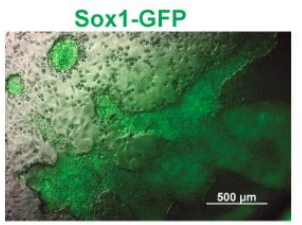

B

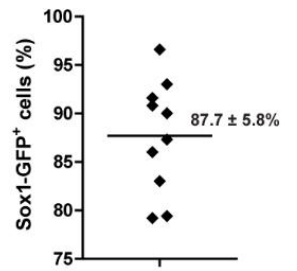

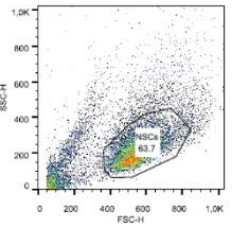

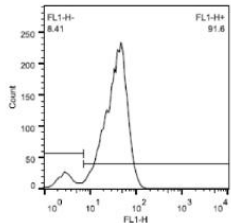

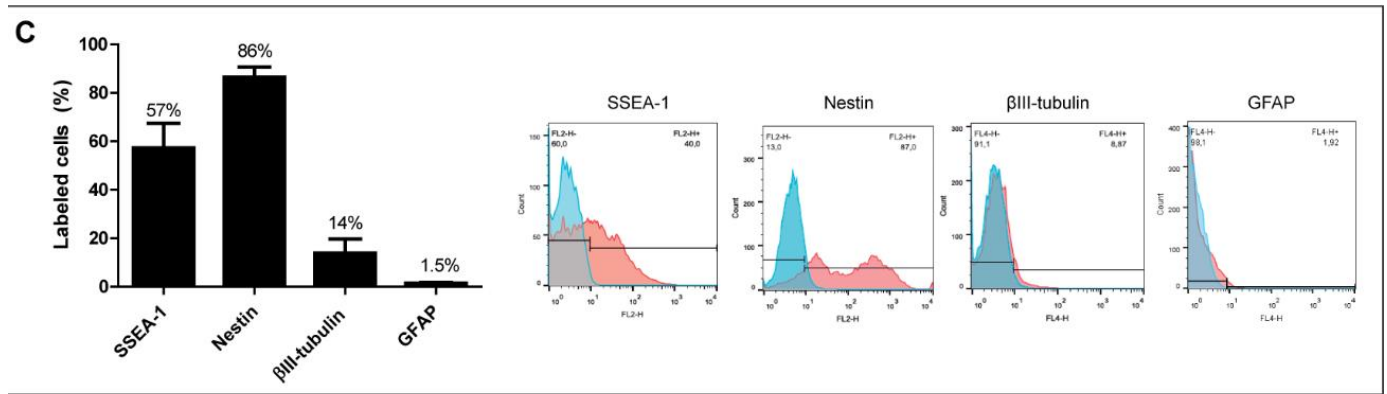

Figure S1. Phenotypic characterization of mES-NSPCs at day 5 of monolayer neural commitment. (A) Representative fluorescence image of the monolayer culture showing cells expressing Sox1-GFP (early neuroectodermal marker) after neural phenotypic induction. (B) Percentages of Sox1-GFP' cells attained in the different neural commitments performed as assessed by flow cytometry; live cells were gated using forward scatter (FSC, reflecting size) and side scatter (SSC, reflecting complexity) criteria, and fluorescence gates set using undifferentiated $46 \mathrm{C} \mathrm{ES}$ cells; a representative dot plot and fluorescence intensity histogram is shown. (C) Immunocytometric analysis of SSEA-1 (mouse embryonic stem cells), nestin (neural stem/progenitor cells), Blll-tubulin (developing and mature neurons) and GFAP (astrocytes) expression ( $N=3$ independent experiments); fluorescence intensity histograms from a representative experiment are shown; the blue histogram represents the fluorescence of cells incubated only with the isotype-specific secondary antibody. 


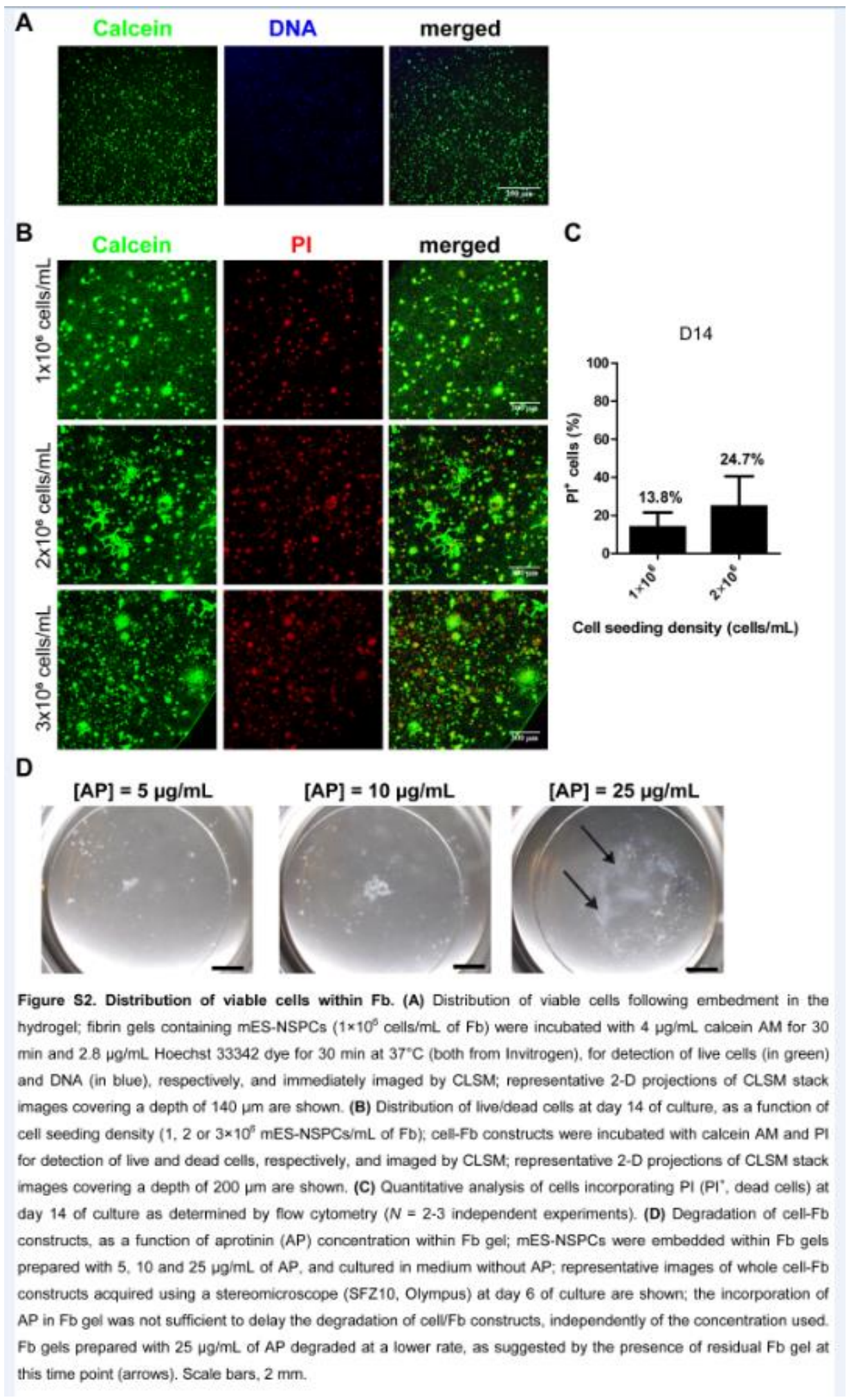
Version: Postprint (identical content as published paper) This is a self-archived document from i3S - Instituto de
Investigação e Inovação em Saúde in the University of Porto Open Repository For Open Access to more of our publications, please visit http://repositorio-aberto.up.pt/ 
A

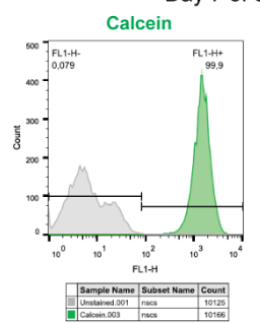

Day 7 of cell culture

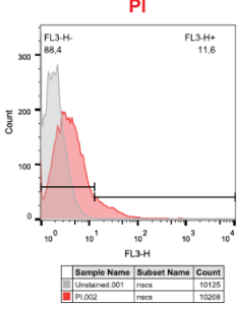

Day 14 of cell culture
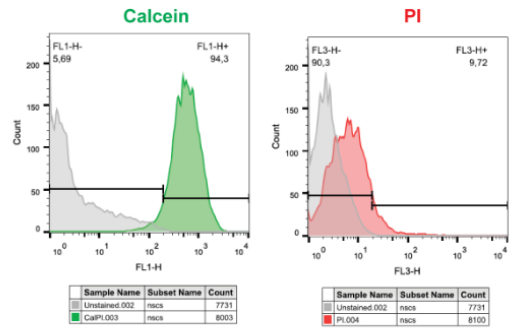

GFAP

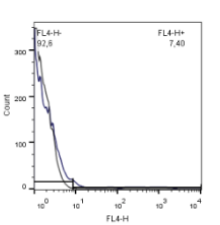

$\mathrm{O} 4$

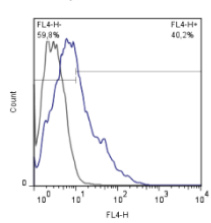

B
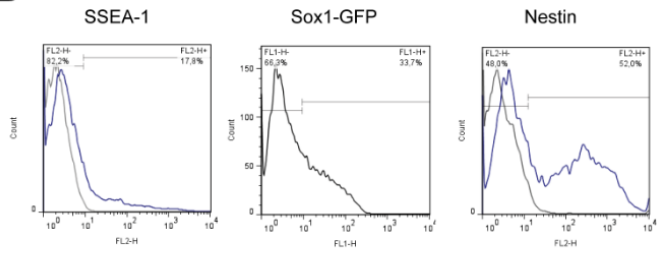

Figure S3. Representative flow cytometry fluorescence histograms correspondent to: (A) Live/dead assay performed at day 7 and 14 of mESNSPC culture within Fb; cells were isolated from the cell/Fb constructs, incubated with calcein AM and PI (for detection of live and dead cells, respectively), and analysed by flow cytometry. (B) Phenotypic characterization of mES-NSPCs cultured within Fb for 14 days: SSEA-1 (mouse embryonic stem cells), Sox1-GFP (early neuroectodermal cells), nestin (neural stem/progenitor cells), Blll-tubulin (developing and mature neurons), GFAP (astrocytes), and $\mathrm{O} 4$ (olygodendrocytes); the grey line represents the fluorescence of cells incubated with secondary antibody only or with the correspondent isotype control.

Rua Alfredo Allen, 208 4200-135 Porto 


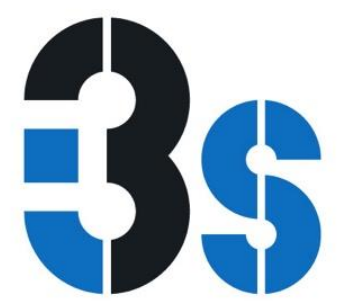

A

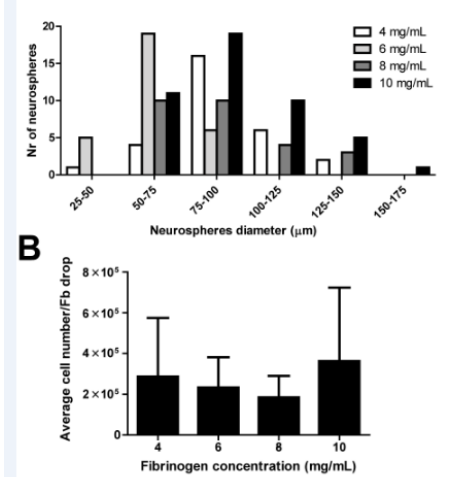

C
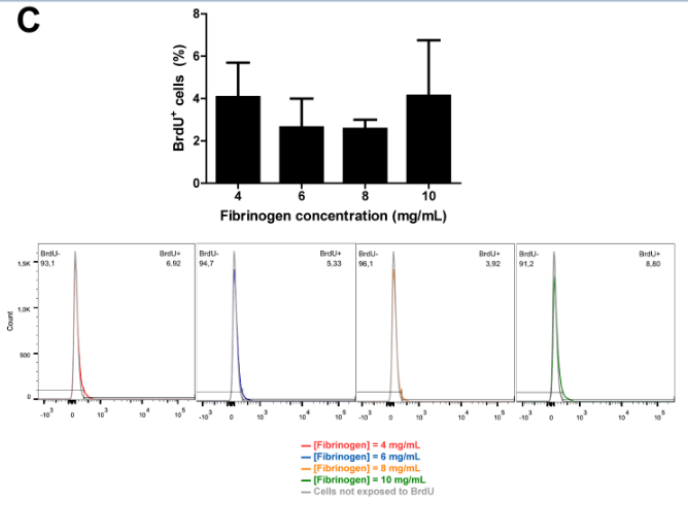

D

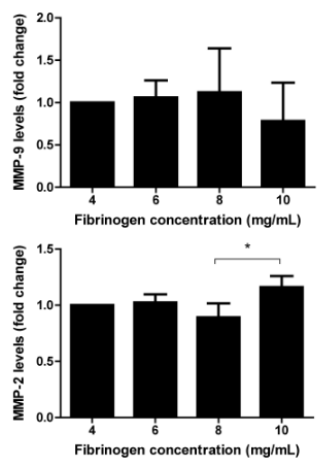

Figure S4. Effect of fibrinogen concentration on cellular spheroid diameter, total cell number, percentage of proliferative cells, and MMP activity, at day 14 of mES-NSPC culture within Fb. (A) Histogram of cellular spheroids diameter distribution as a relative frequency ( $N=252-373$ spheroids); large cellular spheroids (diameter $>125 \mu \mathrm{m}$ ) were only observed in $\mathrm{Fb}$ gels formed with the two highest fibrinogen concentrations tested (6 and $8 \mathrm{mg} / \mathrm{mL}$ ). (B) Total cell number per $\mathrm{Fb}$ drop after cell isolation from cell/Fb constructs ( $N=3-6$ independent experiments). (C) Percentage of proliferative cells assessed by BrdU incorporation and flow cytometry ( $N=3-4$ independent experiments); representative fluorescence histograms are shown; the fluorescence of cells not exposed to BrdU but processed in parallel for immunodetection of $\mathrm{BrdU}$ is also shown; varying the fibrinogen concentration did not significantly alter the total cell number per drop neither the percentage of proliferative cells $\left(\mathrm{BrdU}^{+}\right.$cells) in the range of fibrinogen concentrations tested. (D) MMP-2 and MMP-9 activity present in cell culture conditioned media, as determined by gelatin zymography; MMP-activity levels were normalized to those of the lowest fibrinogen concentration tested $\left(N=3\right.$ independent experiments; ${ }^{*}, p<$ 0.05); apart from the difference found between MMP-2 activity levels obtained for fibrinogen concentrations of 8 and $10 \mathrm{mg} / \mathrm{mL}$, no significant differences were among the fibrinogen concentrations tested, independently of the MMP considered. 